\title{
Marcelo Caetano e a sua circunstância rumo à liderança: poder simbólico, ambição e adaptação
}

\author{
Pedro Emanuel Mendes ${ }^{1}$ (iD
}

\begin{abstract}
Este artigo apresenta um modelo de acumulação de poder simbólico para explicar a carreira política de Marcelo Caetano e a sua ambição progressiva rumo à liderança do Estado Novo português. Esse modelo, de base reflexiva e sociológica, é aplicado ao nosso caso através de um exercício de reconstrução histórica do percurso político de Marcelo desde a sua entrada nos corredores do poder até a sua ascensão à liderança em 1968. O artigo desenvolve novos argumentos teóricos sobre as carreiras dos líderes políticos e dos seus objetivos de obtenção de capital político e social, em especial da importância de acumulação de poder simbólico em regimes autoritários altamente ideológicos e carismáticos como o do Estado Novo. O seu principal objetivo é apresentar uma visão mais sofisticada e relacional do percurso político de Marcelo Caetano, designadamente da explicitação do dilema de sucessão carismática com que teve que se confrontar, e contribuir para a acumulação de conhecimento teórico e histórico sobre o regime autoritário português.
\end{abstract}

Palavras-chave: Marcelo Caetano; ambição política; Estado Novo; poder simbólico; capital político

\section{Introdução}

É comum ouvir dos líderes políticos o argumento de que nunca fizeram planos e traçaram metas de lugares a atingir. Nos seus discursos públicos, a maioria dos políticos constata que foi uma série de acontecimentos cruzados e de coincidências no tempo e no espaço que permitiu, de forma mais ou menos fortuita, que conseguissem chegar ao poder.

É verdade que a história é impossível de predefinir e que não existem carreiras políticas deterministas nem planos pessoais que, por mais aparentemente perfeitos, não possam ser derrubados por circunstâncias históricas imprevisíveis. Todavia, existem percursos políticos tão extraordinariamente consistentes que põem em causa a visão acidental da liderança política e demonstram como a acumulação de poder simbólico, a ambição estratégica e a capacidade de adaptação desempenham um papel decisivo. A

\footnotetext{
1 Universidade Nova de Lisboa, Faculdade de Ciências Sociais e Humanas (FCSH), Instituto Português de Relações Internacionais (IPRI). Lisboa, Portugal. E-mail: <pemanuelmendes@gmail.com>.

2 Este artigo está escrito em português europeu.
} 
carreira política de Marcelo Caetano é um desses extraordinários casos em que o percurso profissional e político parece destinado a atingir o pódio do poder.

Para além de vários microepisódios e importantes circunstâncias sociais, como as suas amizades, Marcelo foi construindo uma carreira pública tão importante que, quando o líder patriarcal do Estado Novo sucumbiu, a sua subida ao poder era quase obrigatória. É certo que eram outros tempos e outras vontades e que o Estado Novo português era um regime corporativo que valorizava a notabilidade académica e protegia o mérito dos seus, desde que disciplinados, na progressão das carreiras públicas. Mas não deixa de ser excecionalmente completa a trajetória profissional e política de Marcelo Caetano. Com exceção de Salazar, Marcelo é a personalidade política mais consistentemente permanente ao longo do Estado Novo. Essa sua longevidade nas ideias e práticas do aparelho de Estado do regime corporativo português é normalmente assumida como uma prova da sua coerência autoritária e da sua incapacidade de se descolar ideologicamente de Salazar e do Estado Novo.

Contudo, a personalidade política de Marcelo não foi sempre linear. Existiram várias e diferentes fases do seu percurso político que revelam que, para além de uma determinada continuidade de suporte ao regime do Estado Novo, existiram ciclos de mudança na circunstância ideológica e política na vida pública de Marcelo.

Nesse quadro, este artigo traça o percurso político de Marcelo Caetano, desde a sua juventude até 1968 , e avança com uma explicação politológica inovadora para o sucesso da sua carreira política. Este estudo identifica as principais fases e ciclos da vida política de Marcelo, demonstra a sua ascensão social e a consequente acumulação de poder simbólico dentro do regime autoritário português. O artigo obedece a dois objetivos, um histórico e outro teórico. Em primeiro lugar, apresenta, historicamente, as principais continuidades e mudanças do pensamento e ação política de Marcelo ao longo das diferentes etapas da sua vida pessoal, profissional e política, relacionando-as compreensivamente com os contextos políticos, ideacionais e sociais da sua circunstância. Em segundo lugar, problematiza sua carreira política, propondo uma teorização inovadora que tenta adaptar conceitos clássicos da sociologia política - poder simbólico, carisma, capital político, adaptação, socialização - ao caso em análise.

Este texto está organizado em quatro partes, além desta introdução e da conclusão. Na primeira, desenvolve uma contextualização teórica da nossa argumentação e apresenta um modelo de análise de acumulação de poder simbólico, que contribui para a explicação do sucesso das carreiras políticas. As três partes seguintes correspondem à apresentação dos diferentes ciclos de vida profissional e política de Marcelo e traçam, de forma sucessiva, uma análise do seu percurso, desde os seus anos iniciais (inícios do século $\mathrm{XX}$ ), até ao seu regresso ao Conselho de Estado, relativo à discussão sobre a (sua) sucessão de Salazar em 1968. 
O artigo cruza fontes primárias e secundárias e dialoga com os principais trabalhos sobre Marcelo Caetano, apresentando uma interpretação mais multifacetada e relacional do seu percurso político, com destaque para a relação comparativa de Marcelo com Salazar.

Ao contrário de uma visão dicotómica entre História (narrativa/compreensão) e Ciência Política (conceptualização/explicação) (Mendes, 2019c, 2020d, 2021b), este artigo desenvolve uma análise narrativa eclética que integra os factos, as ideias, os contextos e dilemas que caracterizaram o percurso de Marcelo como homem político. Defende três argumentos principais, que percorrem todo o artigo. Primeiro, o percurso político e ideológico de Marcelo não é linear e desenvolve-se ao longo de diferentes ciclos. Segundo, ele foi um líder com uma forte ambição política e construiu a sua carreira estrategicamente, acumulando de forma progressiva poder simbólico e capital político. Terceiro, Marcelo, por um lado, socializou as ideias políticas do seu tempo e, por outro, teve alguma capacidade de aprendizagem e de adaptação política, o que determinou que, em várias ocasiões, o seu nome fosse encarado ora como crítico, ora como indefetível do salazarismo.

\section{Modelo de acumulação de poder simbólico nas carreiras políticas: uma teorização geral e a sua adaptação ao caso de Marcelo Caetano}

Será que um líder político possui caraterísticas pessoais, carismáticas, inatas, que definem sua carreira e seu sucesso político? Ou será que, para além das suas qualidades individuais, existem outras dimensões que influenciam a carreira de um líder político? 0 que é que pode ser mais crucial: as capacidades do líder ou as suas circunstâncias?

O líder político é sempre uma construção relacional com as suas circunstâncias. A ambição política não é uma simples atribuição que nasce por um processo endógeno, mas, antes, é o resultado da interação coconstitutiva entre a agência do ator e as estruturas históricas e ideacionais que o embebem (Giddens, 1984). Parafraseando o famoso aforismo de Ortega y Gasset (1967), todo o ator político é ele e as suas circunstâncias. Também Karl Marx sublinhou que os homens fazem a sua história, embora não nas circunstâncias escolhidas por eles, mas em relação com os constrangimentos históricos nos quais estão inseridos (Marx, 2010, p. 329). Marcelo não foge a esta regra de correlação constitutiva entre a sua agência como homem político e a influência das estruturas sociais e materiais da sua circunstância, bem como do Zeitgeist do seu tempo, nomeadamente as vagas autoritárias e corporativistas que aconteceram na Europa e América Latina (Pinto e Martinho, 2016; Pinto, 2017). Marcelo nasce em 1906, ainda na monarquia constitucional, vive a transição violenta para a República (1910) e os seus ciclos de instabilidade que, finalmente, propiciaram a construção de um Estado Novo autoritário em Portugal ${ }^{3}$. Desde

\footnotetext{
3 O Partido Republicano Português (PRP) desenvolveu uma hegemonia política que erodiu o pluralismo e dificultou o acesso da oposição ao poder e ao Estado. Este domínio refletiu-se no controlo do aparelho de Estado e na negação do seu acesso a outras forças políticas e sociais. Esta hegemonia e a continuação da cultura antimonárquica jacobina e violenta, agora direcionada para a oposição, criaram tensões e dissidências que minaram a legitimidade do projeto democrático do PRP e do próprio regime republicano. A Constituição
} 
cedo, por influência do seu meio familiar e social conservador, católico e antirrepublicano, assume uma visão crítica do regime republicano português que o leva a abraçar, na juventude, movimentos nacionalistas radicais antirrepublicanos como o Integralismo Lusitano (Martinho, 2016; Martins, 2004). Como o caso em estudo demonstra, as circunstâncias e os contextos históricos das vagas autoritárias foram importantes.

Contudo, em função da problemática da afirmação da liderança de Marcelo, no contexto autoritário português importa questionar o seguinte: existem dimensões simbólicas de acumulação de capital social e político que permitem que um ator político construa e solidifique a sua imagem de líder? Qual o papel do poder simbólico na afirmação da ambição política de um líder?

O nosso argumento, que aplicamos a Marcelo Caetano, é que existe uma dimensão decisiva na afirmação da liderança política, que é a capacidade de acumular poder simbólico, ou seja, a capacidade de o ator político ser reconhecido como líder carismático, desenvolver aptidões de socialização adaptativa das ideias e práticas do seu tempo e aproveitar de forma ambiciosa e estratégica as oportunidades dadas pelas circunstâncias dos momentos políticos. Como problematizamos, será a capacidade de acumular poder simbólico que contribui decisivamente para o sucesso de uma carreira política?

Partindo destas questões, propomos um modelo de análise dinâmico, que designamos acumulação de poder simbólico, para explicar uma maior probabilidade de sucesso nas carreiras políticas e, especialmente, explicar a carreira política de Marcelo Caetano rumo à liderança do Estado Novo português em 1968.

Esse modelo tenta conjugar duas importantes tradições teóricas na Ciência Política. A primeira é a tradição racionalista ligada às lógicas explicativas do homo economicus e às suas deliberações racionais e estratégias de max min. Isto é, a tentativa de explicar as decisões políticas através da lógica racional de maximização de ganhos e minimização de custos. Esta tradição baseia-se na explicação das escolhas racionais e estratégicas dos políticos, nomeadamente nas suas deliberações face aos constrangimentos da situação, bem como do aproveitamento das oportunidades apresentadas de avançar nas suas carreiras políticas (Schlesinger, 1966; Black 1972; Rohde 1979; Herrick e Moore 1983; Fowler e McClure 1989; Francis e Kenny, 2000; Maestas et al. 2006).

Esta tradição introduziu a importante ideia da ambição política e do seu impacto na progressão das carreiras políticas. Embora tenha sido Eulau (1962) o primeiro cientista político a operacionalizar ${ }^{4}$ a influência que as estratégias de progressão na carreira têm no

de 1911, altamente parlamentarista, legitimou aquilo que era percecionado pela oposição como "uma ditadura de partido" (Baiôa, 2004). Foi contra esta cultura que vários movimentos dissidentes começaram a lutar, muitas vezes, juntando-se aos conservadores, monárquicos e católicos, que tinham perdido privilégios de domínio político e económico. Com isto, o regime começou a tornar-se sistemicamente instável e originou a procura da ordem, que surgiu com o sidonismo, que foi um "interlúdio autoritário" (Pinto, 2004) até ao surgimento da nova ordem com o salazarismo.

4 Sobretudo na lógica empírica da Ciência Política, uma vez que, na lógica da Teoria Política clássica, a ideia de ambição política está razoavelmente presente, ainda que, muitas vezes, implicitamente. Todavia, existem autores que se dedicam explicitamente a esta conceção, veja-se, por exemplo, Helfer (2017), obra em que 
comportamento dos atores políticos, foi Schlesinger (1966) que escreveu a obra fundacional que explica a ambição política e as suas principais motivações. Logo na abertura do seu livro, o autor afirma: "Ambition lies at the heart of politics. Politics thrive on the hope of preferment and the drive for office" (p. 1). Esse princípio básico é universal, e, ainda que a esmagadora maioria dos estudos sobre a ambição política seja aplicada em regimes democráticos, mais ou menos competitivos, esta ideia também se aplica a regimes autoritários, nos quais a ambição competitiva é menos clara e institucionalizada, mas igualmente importante.

Outra ideia fundacional de Schlesinger é relativa à ambição progressiva dos políticos. O seu principal argumento é que os políticos são animais ambiciosos por definição e que, desde a entrada na vida política, o seu principal leitmotiv é a ambição de ocupar cargos e progredir na hierarquia o mais longe possível, idealmente até o topo dos cargos políticos, aquilo que, neste artigo, designamos por liderança, que no nosso caso equivale à chefia do governo do Portugal autoritário ${ }^{5}$. De forma pioneira, Schlesinger demonstra que a ação dos atores políticos é fortemente determinada pela ambição de alcançar melhores cargos políticos - "a ambição progressiva" - ou manter os cargos que se conseguiram atingir, "a ambição estática" (Schlesinger, 1966).

O outro argumento importante do autor é a demonstração de que a ambição política é condicionada pela estrutura de oportunidades e de disponibilidade dos cargos, bem como pelo contexto institucional e normativo que limita e regula a competição eleitoral específica dos cargos em disputa. Com base nestas ideias seminais, foram realizados inúmeros estudos empíricos que comprovam os seus argumentos principais sobre a importância da ambição política6.

No nosso caso, interessa-nos a ambição progressiva, a ponderação racional e estratégica de Marcelo, incluindo as suas caraterísticas pessoais (Mendes, 2020a). Em especial, a sua capacidade de socializar e defender as ideias do regime ${ }^{7}$, bem como de

o autor trabalha a visão da ambição política nas perspetivas clássicas de Platão e Aristóteles. Trata-se do dilema da carreira do homem político que se vê confrontado com o prestígio e a honra de servir o bem público e a polis, com base na preparação intelectual dos jovens para a política através de uma educação ideal, e a prática política de ambição e de manutenção do poder pessoal que corrompe a ideal ambição política inicial de apenas servir o bem público. No clássico de Aristóteles (1991), Ética a Nicômaco, observam-se algumas das virtudes políticas que um líder pode e deve almejar. Neste caso, talvez seja útil para a compreensão do espírito de missão do estadista nacionalista, que Marcelo também evocou na sua vida política. Embora esse espírito de serviço público também tenha tido influência na sua ascensão política, como argumentamos, esse aspeto não foi distintivo de outros líderes do Estado Novo, ao contrário do nosso argumento sobre a importância da acumulação de poder simbólico.

5 Institucionalmente, a designação chefe de governo no período autoritário era o de Presidente do Conselho. Para além deste, que concentrava os poderes executivos, existia ainda o Presidente da República, que tinha poderes muito limitados, mas que, no caso do marcelismo, teve um relativo peso político (Mendes 2020a; 2020c).

${ }^{6}$ Desde 1966 até hoje, centenas de estudos comprovam e desenvolvem estas ideias, sobretudo em regimes democráticos nos quais a vida política se tornou altamente profissional. Em português, veja-se Messias (2019) e Miguel (2003).

7 O que não significa, como também identificamos, que Marcelo não fosse igualmente um ator político com um pensamento crítico de várias das ideias e práticas dominantes da elite salazarista e da própria gestão governativa de Salazar. Por exemplo, a sua capacidade de criticar publicamente a criação paradoxal de um 
adaptação política face aos constrangimentos de cada situação particular, nomeadamente perante os convites e desconvites que teve de gerir na sua carreira política.

Para além da ambição, o político de sucesso tem de ter uma boa capacidade de adaptação, bem como uma boa capacidade de socializar as ideias políticas dominantes e úteis para se integrar e ascender na hierarquia política do regime, em especial nos regimes autoritários que constroem identidades políticas e ideológicas particulares, como foi o caso do Estado Novo e da sua identidade autoritária, imperial e autárcica (AIA) (Mendes, 2018). Esta capacidade de socialização ideacional é ainda mais relevante quando o político é capaz de ser um produtor de ideias e doutrinas políticas úteis para a consolidação ideológica do regime, como foi o caso de Marcelo Caetano.

As ideias de adaptação e socialização interligam-se já com a segunda tradição teórica que iremos trabalhar. Estamos a falar da tradição sociológica e reflexiva, atualmente também conhecida por construtivista ${ }^{8}$. Esta abordagem argumenta que, para além da lógica racional, existem outras lógicas que explicam as decisões e o comportamento dos atores políticos (Mendes, 2018, 2020b). Para além da deliberação racional, é necessário olhar para o decisor político, não apenas como um homo economicus, mas, sobretudo, como um homo sociologicus. Ou seja, apesar de o ator político agir racionalmente, a sua deliberação racional é sempre uma construção determinada pela sua identidade política e social, pelas suas ideias, habitus e práticas, bem como pelo ambiente histórico e político onde está embebido que, de forma simultânea, influencia e constitui a sua ação política.

Isto significa que, embora, por definição, todos os políticos sejam altamente racionais e ambiciosos na gestão das suas carreiras políticas, uma análise sofisticada da carreira de um político deve ter em consideração a importância decisiva do contexto e das circunstâncias políticas e históricas em que o político está imerso.

Não se trata apenas de considerar o surgimento das oportunidades que em determinado momento e contexto político estão disponíveis e das capacidades dos políticos de as aproveitarem. Trata-se de perceber que as próprias oportunidades têm contextos materiais e ideacionais que constroem socialmente as ambições e decisões dos políticos, isto é, os impactos dos constrangimentos estruturais das carreiras políticas não podem explicar-se desligados das perceções e leituras individuais dos políticos. Para além do cálculo racional do risco, as oportunidades de avançar na carreira política são sempre

ministério das corporações, a sua visão própria, e muitas vezes dissidente, sobre opções políticas decisivas, como a escolha republicana em detrimento de um possível retorno monárquico, a sua discordância com as invasões policiais nas Universidades, a sua visão autonomista e não integracionista face à política colonial dominante, a sua visão menos paroquial e mais desenvolvimentista etc. Também por isso, defendemos que o salazarismo não é o marcelismo. Contudo, para o problema aqui discutido, a nossa argumentação é a de que esta capacidade de ter um pensamento próprio, mesmo crítico, é resultante da sua acumulação de poder simbólico e da sua tentativa, por vezes frustrada, de se afirmar como um líder com capital político e poder simbólico capaz de se constituir como alternativa à liderança de Salazar.

${ }^{8}$ A obra fundadora do Construtivismo é a de Berger e Luckmann (1966); posteriormente o Construtivismo afirmou-se, sobretudo, a partir das Relações Internacionais, no seguimento do trabalho pioneiro de Onuf (1989), afirmando-se como uma das suas teorias principais (Mendes, 2012, 2019b). 
interpretadas pelos políticos de acordo com as suas caraterísticas identitárias e ideacionais, também conhecidas como imagens culturais dos decisores (Mendes, 2018).

Partindo desta visão sociológica e construtivista geral, o nosso modelo de análise desenvolve uma (re)interpretação das teorizações de Pierre Bourdieu relativas ao "campo político", ao "poder simbólico", ao "capital político" e ao "capital social" (Bourdieu, 1980, $1983,1985,1989)$. A abordagem reflexiva e relacional do pensamento sociológico do autor é especialmente sensível aos contextos e à reflexividade particular de cada campo político ${ }^{9}$. Por isso, as suas ideias seminais sobre o poder simbólico e a atividade política são especialmente adaptáveis à análise do Estado Novo português.

$\mathrm{Na}$ realidade, para o entendermos bem é importante percebermos as suas especificidades de "campo político" autoritário, altamente ideológico, simbólico e carismático. O regime autoritário português é um caso paradigmático da importância do poder simbólico e dos seus "instrumentos" (Bourdieu, 1989, p. 16). No Estado Novo, os símbolos, os rituais políticos e a celebração nacionalista dos heróis e dos feitos dos portugueses eram, simultaneamente, produto de ensino e doutrinação da população e de legitimação da ação governativa autoritária e imperial (Mendes, 2020b).

Mais do que uma política de imposição violenta de poder totalitário bruto, o Estado Novo construiu uma ideologia de poder autoritário suave que se traduziu na construção ideológica e respetiva socialização simbólica de uma maneira portuguesa de governar baseada num autoritarismo patriarcal mais simbólico do que violento. Um autoritarismo corporativo, conservador, católico, nacionalista - aparentemente benigno para o mundo ocidental - assente num simbólico triângulo identitário (Mendes, 2020b) e com uma forte carga de violência simbólica ${ }^{10}$.

Como exemplifica o caso do Estado Novo português, o poder simbólico constrói-se e autolegitima-se através de um discurso ideológico que edifica e socializa uma realidade particular. Isto remete para outra dimensão fundamental do poder simbólico, que é o poder de construir a realidade (Bourdieu, 1989, p. 9) e interliga-se com a visão construtivista sobre a construção das interpretações do mundo e suas respetivas assunções (Onuf, 1989; Mendes; 2018; 2020b). Na nossa ótica, esta visão é útil para compreendermos melhor os campos políticos autoritários, que tendem a construir um mundo subjetivo monista e relativamente alternativo ao mundo objetivo e plural da realidade ${ }^{11}$.

\footnotetext{
${ }^{9}$ Embora também fale do caso soviético, Bourdieu desenvolve a sua análise, essencialmente, a pensar nos regimes democráticos ocidentais e não em regimes autoritários. Contudo, aqui importa sublinhar o carácter específico, autoritário, do campo político do Estado Novo português.

10 Isto remete para a discussão sobre o uso da violência bruta no salazarismo e o relativo reduzido número de vítimas mortais em comparação com outros regimes autoritários fascizantes da época. Contudo, importa chamar a atenção para o fato de que as caraterísticas da violência nos regimes autoritários, e a sua denúncia crítica, não se podem qualificar numa lógica aritmética. Na nossa ótica, o Estado Novo português não deve ser, mal, comparado com outros tipos de regimes relativamente à quantidade de vítimas mortais, mas deve ser, bem, caraterizado por ser um regime com um especial cinismo na produção de violência simbólica.

${ }^{11}$ Compreender isto é importante mesmo nos regimes democráticos atuais, sobretudo onde o neopopulismo se afirma e se manifesta numa crescente polarização ideológica, política e interpretativa da realidade. Neste processo de polarização populista, é constatável a construção intersubjetiva de mundos políticos e culturais
} 
PEDRO EMANUEL MENDES

No âmago do poder simbólico está "esse poder invisível" que reflete o reconhecimento cúmplice dos governados (Bourdieu, 1989, p. 7-8). O poder simbólico baseia-se no reconhecimento da legitimidade dos que detêm e exercem o poder, e na crença por parte dos governados de que quem os governa tem capacidades extraordinárias e especiais para os governar (Bourdieu, 1989, p. 188-189). O poder simbólico assenta na capacidade de alcançar o respeito e a obediência dos governados através do reconhecimento das qualidades do líder político para conduzir os destinos do Estado.

Ora, precisamente, o Estado Novo, para além da criação de um regime institucional, foi, acima de tudo, a criação de um regime de poder simbólico com base na obediência ao seu criador carismático: Oliveira Salazar. Por isso, o Estado Novo se confunde com o salazarismo e é indissociável da construção de poder simbólico autoritário do seu líder e do seu reconhecimento carismático. Isto significa que nada se compreende cabalmente no Estado Novo sem uma análise relacional com Salazar. Para explicar a ambição política de Marcelo e a gestão estratégica da sua carreira política, é fundamental incluir na equação uma análise comparada com Salazar.

Como demonstrámos, Salazar tem uma influência decisiva na carreira política de Marcelo e na sua ambição progressiva. Primeiro como role model e depois no permanente diálogo, simultaneamente leal e crítico, com Salazar, que se explica pela necessidade de Marcelo ser reconhecido, mas também de se autonomizar como ator político com uma personalidade política própria, embora sem nunca extinguir o mito carismático do salazarismo. Esse foi o grande desafio da ambição política de Marcelo: como se transformar no candidato natural à sucessão de Salazar.

Esse desafio, por um lado, impôs a Marcelo a necessidade de acumulação de poder simbólico que Ihe permitisse uma comparação carismática com Salazar e consequente reconhecimento e crença de que ele seria o seu continuador, por outro lado, para construir esse poder simbólico alternativo a Salazar era fundamental consolidar uma imagem de independência e de originalidade face às ideias do salazarismo. Esse complexo dilema da sucessão carismática de Salazar irá ser um fantasma político que ensombrará a carreira política de Marcelo, sobretudo o seu consulado (Mendes, 2013; 2020c).

Outra ideia de Bourdieu que adaptamos ao nosso modelo é a de "capital político" e das suas várias "espécies" (Bourdieu, 1989, p. 190). Bourdieu sublinha que, tal como um capitalista, o político, para se tornar relevante, tem de adquirir e acumular capital. De acordo com o autor, o líder político acumula capital político através de duas formas principais. Em primeiro lugar, por meio do seu "capital pessoal de notoriedade e popularidade" (p. 193), isto é, das suas qualidades pessoais, profissionais, técnicas, carismáticas, intelectuais, emocionais e de liderança ao longo da sua vida e de forma relativamente independente do campo político. Em segundo lugar, o político acumula capital político por intermédio do "capital delegado", isto é, do capital político que advém

opostos e quase alternativos: a realidade populista e pós-verdadeira versus a realidade crítica do populismo e da pós-verdade. 
da função exercida dentro do campo político, aquilo que Bourdieu chama de "capital de função" (Bourdieu, 1989, p. 193).

Adaptando estas ideias ao nosso caso, o modelo que apresentamos começa por considerar que o poder simbólico é a mais alta expressão de poder ${ }^{12}$, pois integra o capital social e político. Por um lado, é um poder constitutivo da própria realidade política e social. Por outro, influencia a formação dos próprios sistemas práticos e institucionais de obtenção de poder político, como os partidos, as doutrinas e normas, bem como as instituições governativas. O poder simbólico assenta na capacidade de produzir ideias e fazer com que estas construam a realidade. Através de uma socialização ideacional e da assunção de entendimentos partilhados pelas elites (Mendes, 2018, 2020b), o poder simbólico formata ideias e perceções dominantes - quer acerca do campo político, quer acerca da sociedade em geral -, fazendo com que essas ideias e essa realidade sejam aquelas que fazem sentido. Desse modo, é o poder simbólico que, de forma decisiva, ajuda a construir socialmente a realidade política.

O poder simbólico é constituído de forma simultânea e conjugada por duas vertentes principais de capital: o capital social e o capital político.

\section{Figura 1 \\ O poder simbólico é a soma de capital social e capital político $(\mathbf{P S}=\mathbf{C S}+\mathrm{CP})$}

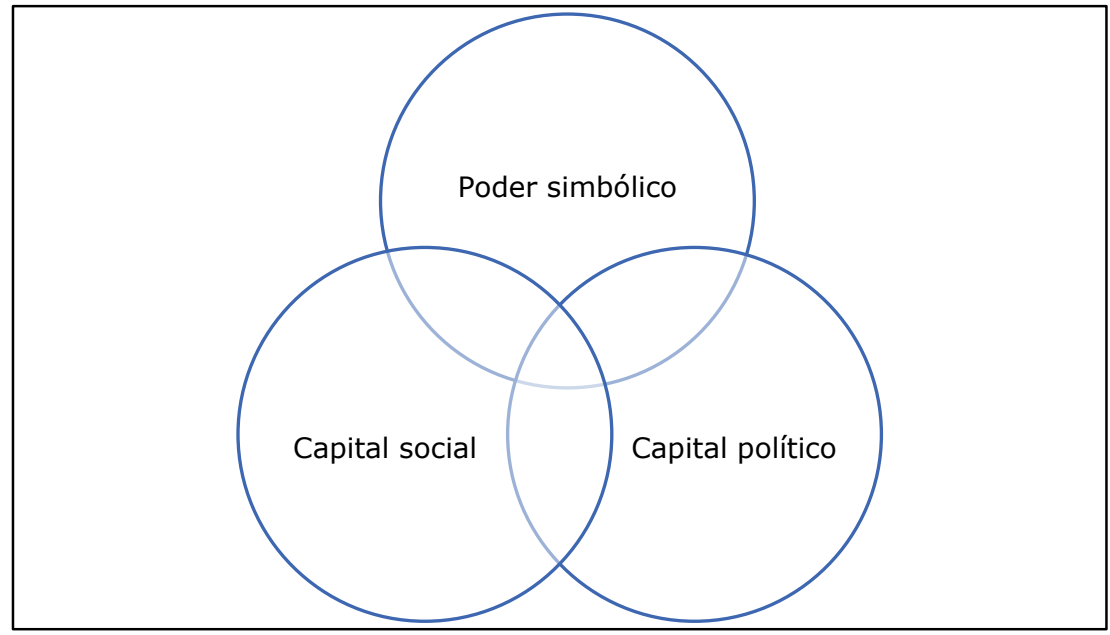

Fonte: Elaboração do autor.

\footnotetext{
12 Na lógica da explicação da ambição estratégica progressiva das carreiras políticas rumo à liderança, esta lógica do nosso modelo tem caraterísticas universais a vários tipos de regime. Isto significa que o nosso modelo pode ser adaptado a outros casos, mas ele capta melhor a lógica da ambição das carreiras políticas nos regimes autoritários, ideológicos, simbólicos e carismáticos. Embora comporte caraterísticas gerais e universalizáveis, a invenção deste modelo é fruto da investigação histórica relativamente à cultura política do Portugal contemporâneo, em especial do seu regime político autoritário.
} 
O capital político é o capital que o político acumula dentro do campo político e que se reflete na sua capacidade de avançar progressivamente dentro do sistema político e de se afirmar como líder ou, pelo menos, como candidato a líder. Esse capital exprime-se pela capacidade de o político mobilizar recursos, nomeadamente institucionais - partidos, sindicatos, associações profissionais e de classe, departamentos do Estado e meios de comunicação de massa -, financeiros - para pagar e financiar campanhas e formas de promoção de imagem - e humanos, quer ao nível do número de seguidores militantes dentro dos aparelhos institucionais, em especial dos partidos políticos -, quer ao nível de seguidores simpatizantes que, sobretudo, em democracia, se exprime em número de $\operatorname{votos}^{13}$. No final, em regimes democráticos, esse é o recurso mais valioso, quer dentro do aparelho político, quer, sobretudo, em atos eleitorais. Os recursos humanos também são importantes nos regimes não democráticos, embora aqui, tão ou mais valiosos do que os recursos humanos, sejam os recursos institucionais, nomeadamente os instrumentos de hegemonia e controlo do aparelho do Estado.

Figura 2

O capital político resulta da acumulação de recursos humanos, recursos financeiros e recursos institucionais ( $C P=R H+R I+R F)$

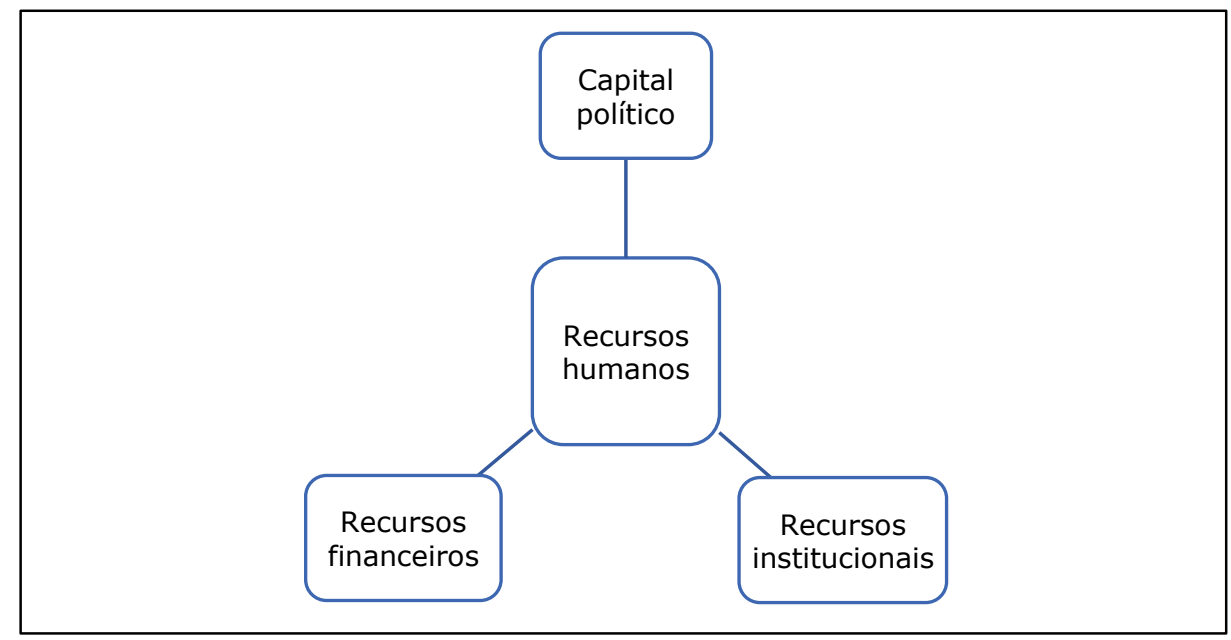

Fonte: Elaboração do autor.

O capital social é o capital que o líder vai acumulando ao longo da sua vida pessoal e que se reflete na sua capacidade de integração na sociedade civil, de desenvolver redes de conhecimento social e de se notabilizar e se tornar (re)conhecido em diversas esferas

13 Nos regimes autoritários, não ideológicos, exprime-se, sobretudo, na quantidade e qualidade de redes clientelares e de patronagem. Nos regimes autoritários ideológicos, para além das tradicionais redes de interesse material, também é necessário considerar as redes de lealdade ideológica. Como explicamos, o Estado Novo era um regime autoritário altamente ideológico, e a lealdade à ideologia contava bastante. 
da vida social e comunitária ${ }^{14}$. Esse reconhecimento social é tradicionalmente adquirido em profissões de carácter público e com algum grau de expressão de poder simbólico.
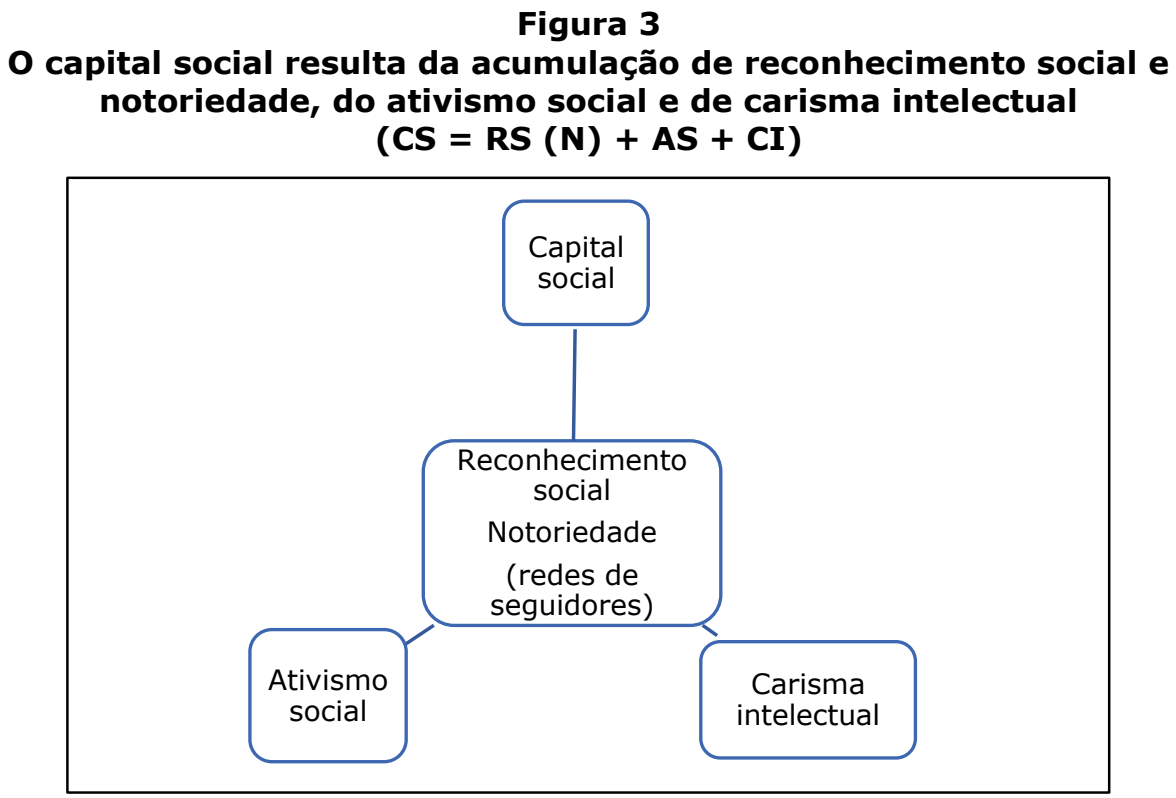

Fonte: Elaboração do autor.

Embora mais intangível, o capital social exprime-se pela capacidade de o líder demonstrar reconhecimento da sociedade civil e canalizá-lo para uma lógica de rede social de apoio. O capital social do líder reflete-se na sua participação em movimentos e associações de grupo ou em rede e na sua capacidade de se tornar reconhecido para além da lógica local, profissional e do estrito campo político. Aqui, ganha particular importância a capacidade de o líder publicar, ou ser publicado, nos meios de comunicação de massas, especialmente nos jornais, que permanecem o principal meio de definição da agenda do campo político. Por outro lado, e cumulativamente, o líder adquire capital social quando é socialmente reconhecido como tendo uma excecional capacidade técnica ou intelectual, aquilo que aqui designamos de carisma intelectual.

\footnotetext{
${ }^{14}$ As suas raízes podem encontrar-se em Durkheim, nomeadamente na sua análise sobre as consequências positivas da participação na vida social em grupo e na interação dos indivíduos com a comunidade como antídoto para a anomia, para a quebra da empatia social e da solidariedade. Contudo, foi Bourdieu o primeiro a sistematizar uma definição sobre o capital social. Para o autor, este capital é "o agregado dos recursos efetivos ou potenciais ligados à posse de uma rede durável de relações mais ou menos institucionalizadas de conhecimento ou reconhecimento mútuo" (Bourdieu, 1985, p. 248). Posteriormente, vários cientistas sociais utilizaram e readaptaram o conceito, mas foi Putnam (1995) quem conseguiu ser mais reconhecido na sua operacionalização em trabalhos em que sublinha que o declínio do "engajamento cívico", da "conetividade social" e da "confiança social" reflete-se no declínio do desenvolvimento económico, normativo e político dos Estados. Como se verifica, a nossa interpretação é diferente porque é operacionalizada relativamente à ambição progressiva das carreiras políticas no quadro da acumulação de poder simbólico e, em especial, ao nosso caso.
} 
Atualmente, nos regimes democráticos, o carisma intelectual tem perdido peso relativo e tem sido substituído pela importância do carisma comunicacional, em que mais do que as ideias, o que importa é a capacidade do líder de comunicar-se emocional e empaticamente.

Contudo, no Estado Novo português, o carisma intelectual era muito importante, uma vez que Oliveira Salazar construiu e acumulou muito do seu poder simbólico com base no carisma intelectual. O Estado Novo português só foi possível pela construção simbólica e carismática do seu líder. Embora não seja possível compreender esta construção sem a conjugação de capital social dos movimentos católicos e conservadores que apoiaram Oliveira Salazar (Cruz, 1998), a sua meteórica carreira política rumo à liderança explicase, em grande parte, pelo seu carisma intelectual que se sublimou na sua capacidade de sanear as finanças portuguesas. Em termos comparativos, Salazar construiu uma imagem carismática mais eficaz do que Marcelo porque a sua ascensão política foi mais rápida e marcada por um importante episódio carismático ${ }^{15}$. Isto não significa que Salazar fosse um líder naturalmente carismático, possuidor de um carisma puro (Weber, 2004). Por comparação com os tipos-ideias de líderes autoritários, ele não tinha as capacidades de comunicação e empatia fascista-populistas, como, por exemplo, Mussolini. Pelo contrário, Salazar não exibia as características tradicionais de imagem, comunicação e emocionalidade diretas com os seus seguidores, típicas de um político carismático tradicional (Martinho, 2013) ${ }^{16}$. Contudo, o contexto político da sua rápida ascensão à liderança e a sua capacidade de agregar e gerir as várias correntes políticas adversas ao republicanismo liberal e democrático solidificaram uma rápida relação de reconhecimento carismático. Como argumentamos, a sua afirmação carismática foi construída rapidamente devido ao contexto de relativo caos político-financeiro em Portugal, à sua capacidade

\footnotetext{
15 No caso de Salazar, foi o seu aparecimento e desaparecimento e, finalmente, o seu retorno ao poder para impor a ordem nas finanças e a salvação da bancarrota. Apesar de ainda hoje ser possível identificar estes episódios, atualmente, mais do que carismáticos, no sentido clássico do termo, estamos perante o que podemos designar por episódios de heroicização dos líderes, em que, mais do que demonstrar as suas qualidades excecionais, eles produzem teatralizações heroicas diante das crises ou eventos que comportam algum nível de crise. Isto é claro, por exemplo, com Trump e Bolsonaro. Tal teatralização heroica é, aliás, conjugada com narrativas pós-verdadeiras que acentuam o caráter emocional do discurso dos líderes, o que se interliga com a "desmitização das lideranças" e com a capacidade dos líderes de se profissionalizarem na gestão do "parodoxo da verdade" e na produção de "verdades arredondadas" (Mendes, 2019a).

${ }_{16}$ Com efeito, posteriormente ao episódio carismático de "salvação financeira", a liderança de Salazar passou a institucionalizar-se, sobretudo, numa lógica de dominação autoritária que pode ser interpretada à luz de vários argumentos de Weber (2004) sobre "as estruturas e funcionamento da dominação", designadamente a lógica de dominação carismática "política" (ordem nova, homem novo) com elementos da dominação tradicional (história, passado), bem como com elementos de dominação burocrática legal (regime autoritário legalista do Estado Novo). Isto significa que o salazarismo não foi um regime carismático tradicional popular e emocional. Contudo, a nossa teorização sobre o poder simbólico e o carisma intelectual com base no pensamento de Bourdieu parece-nos a opção mais operacional para desenvolver a análise relacional das lideranças de Salazar e Marcelo. Salazar, não sendo um líder carismático puro tradicional, construiu uma liderança de reconhecimento carismático hegemónica, principalmente, no seio das elites. Mesmo o povo menos politizado, foi produto de campanhas de propaganda hegemónica que reproduziam a imagem de líder excecional construindo essa ideia mitológico-carismática do ditador português.
} 
técnica, bem como às suas ideias claras sobre a necessidade de impor uma nova ordem nacionalista, conservadora e católica em Portugal.

A ascensão carismática de Salazar é exemplar da clássica visão weberiana, em que o carisma resulta de "uma ação inaugural, realizada em situação de crise, no vazio e no silêncio deixados pelas instituições e os aparelhos: uma ação profética de doação de sentido, que se fundamenta e legitima ela própria" (Bourdieu, 1989, p. 191).

Após obter a liderança, Salazar passou a definir a sua ambição na lógica da manutenção do poder, isto é, na execução de estratégias políticas que consolidassem a sua "ambição estática" (Schlesinger, 1966), até porque não existia mais progressão. Marcelo teve uma carreira política mais longa até chegar à liderança, e os contextos de afirmação carismática política foram mais complexos. Por isso, sublinhamos que Salazar construiu uma liderança carismática hegemónica, enquanto Marcelo nunca conseguiu um reconhecimento hegemónico da sua liderança ${ }^{17}$ (Mendes, 2013). Contudo, o carisma intelectual, e a consequente notoriedade, em ambos os casos, foi um fator decisivo para o reconhecimento da liderança no Estado Novo.

Em termos de capital social, comparativamente com Marcelo, Salazar era menos ativo. Mas não podemos esquecer que, no início da sua carreira, ele também contou com o capital social ligado aos movimentos católicos conservadores e a importantes intuições, como a Faculdade de Direito da Universidade de Coimbra. Mais, posteriormente, a acumulação de poder simbólico de Salazar não pode ser compreendida sem a ligarmos à aliança social que fez com a hierarquia da Igreja Católica Portuguesa, que, durante décadas, ajudou a transferir muito do seu próprio capital social para o apoio a Oliveira Salazar.

Finalmente, importa sublinhar que, ao contrário da lógica da ambição estática de Salazar, Marcelo teve uma ambição política progressiva, mas, como evidenciamos, altamente relacional com a de Salazar, desde logo, porque seria impossível ter uma carreira política progressiva no Estado Novo sem sua aprovação e apoio.

Todavia, o que é interessante destacar é que, enquanto Salazar trabalhava política e simbolicamente para demonstrar a sua utilidade hegemónica no comando do país, apresentando uma excecional capacidade de se prolongar como líder reconhecido pelo campo político autoritário português, Marcelo trabalhava política e simbolicamente para ser reconhecido como o candidato natural à sucessão.

Esse jogo político entre os dois líderes numa situação tradicional (competição institucional e política democrática) resultaria, mais tarde ou mais cedo, num jogo de soma nula e na necessidade de o líder desafiante matar politicamente o líder incumbente.

\footnotetext{
17 Os contextos carismáticos foram muito diferentes no que se refere à capacidade de controlo político, nomeadamente de impor um poder simbólico hegemónico. Numa metáfora, Salazar era como um professor de liceu a falar numa sala para convencer simbolicamente vinte crianças de 12 anos. Marcelo era como um professor universitário a falar num anfiteatro para tentar convencer 200 alunos de pós-doutoramento. Portanto, para além do número de atores que era necessário controlar, era também diferente o nível de contra-argumentação.
} 
PEDRO EMANUEL MENDES

Contudo, isso não aconteceu no Estado Novo, e Salazar sempre conseguiu neutralizar os desafios à sua liderança (Rosas, 2012; Menezes, 2014). Por outro lado, Marcelo nunca conseguiu matar politicamente o salazarismo; aliás, saber se o quereria fazer realmente permanece uma das mais interessantes incógnitas da história do período autoritário português (Mendes, 2020c).

Figura 4

O poder simbólico: um modelo de análise histórico-sociológico dinâmico

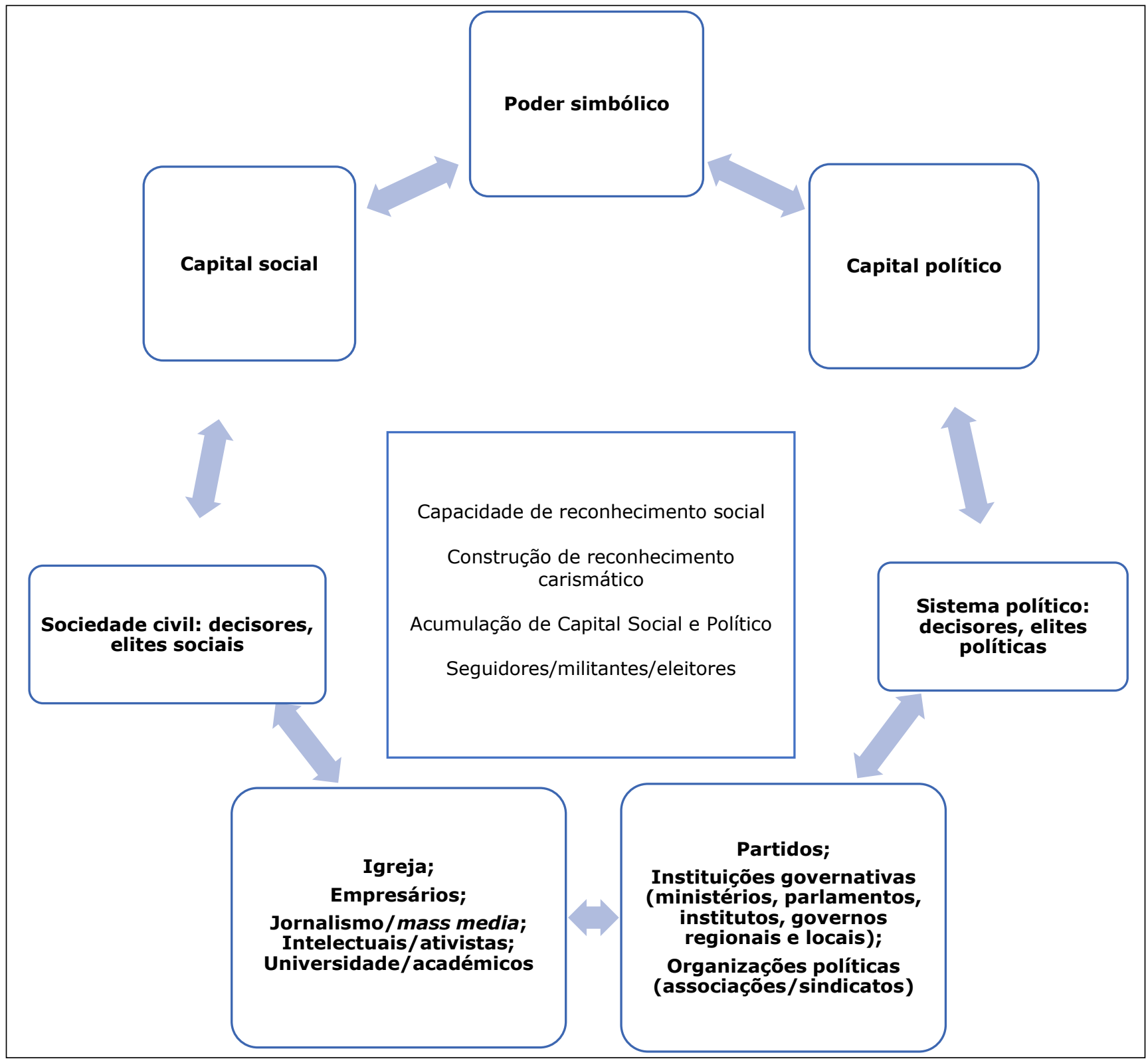




\section{A entrada na política real e a consolidação do seu carisma intelectual: professor, doutrinador e crítico da revolução corporativa do Estado Novo (1929-1944)}

Após um percurso de ascensão social e educacional exemplar, Marcelo termina a licenciatura em Direito na Universidade de Lisboa em junho de 1927 com a classificação final de 18 valores, sem ter ainda completado 21 anos (Martinho, 2016; Mendes, 2020a). Inicia, então, a sua vida profissional e solidifica a sua amizade e cumplicidade, política e profissional, com o seu amigo Pedro Teotónio Pereira. Depois de ambos terem sido jovens líderes universitários da segunda geração integralista, Marcelo e Pedro começam a transitar do Integralismo Lusitano (IL) para o corporativismo do Estado Novo liderado por Salazar (Mendes, 2020a; 2021a).

A liderança carismática e firme de Salazar, fundada no objetivo de impor uma nova ordem nacionalista e conservadora em Portugal, seduz rapidamente os ex-integralistas. Primeiro Pedro e depois Marcelo aderem à liderança de Salazar e começam a entrar nos corredores do poder, abandonando, progressiva e pragmaticamente, os ideais integralistas da juventude. Tudo começou por intermédio de Pedro, que era já uma jovem figura política e tinha um lastro social familiar importante ligado ao mundo empresarial dos seguros. $\mathrm{O}$ seu bisavô havia sido um dos fundadores da Companhia de Seguros Fidelidade em 1835 e o seu Pai era o Presidente da empresa na época. Pedro, apesar de licenciado em Matemática, seguiu a via empresarial da família e viajou para a Suíça para estudar e especializar-se na área. De regresso a Portugal, estava a montar o Ramo Vida na empresa e convidou Marcelo para ser o seu chefe de contencioso.

Nesse quadro, Salazar, então ministro das Finanças, pede a Pedro para se reunir com ele sobre a nova reforma dos seguros em Portugal. Durante as reuniões com o ministro das Finanças surgiam dúvidas e questões jurídicas técnicas. Pedro consultava com Marcelo para o ajudar na preparação às questões levantadas por Salazar, que repara na grande qualidade técnico-jurídica das notas que Pedro trazia. Questionando-o sobre quem era o seu responsável, Pedro explica a Salazar que quem o estava a ajudar era o seu amigo Marcelo Caetano, um grande jurista com excelentes capacidades intelectuais e atributos nacionalistas. Da mesma forma que já tinha pressentido qualidades em Pedro Teotónio Pereira para o apoiar no seu projeto de instaurar uma ordem nova em Portugal, Salazar confia na sua capacidade de análise para captar mais um jovem talento para a sua causa. Após a recomendação elogiosa e "pormenorizada" de Pedro, Salazar manda chamar Marcelo para se encontrar com ele em sua casa e prontamente o convida para trabalhar no seu poderoso Ministério das Finanças como Auditor Jurídico (Caetano, 1977).

Com apenas 23 anos, Marcelo entra para o Ministério das Finanças pela mão do novo homem forte do governo. Será a sua porta de entrada no campo político português. Apesar de sentir alguma frustração em não ser mais aproveitado, a que não era alheio o acesso difícil ao ministro, o jovem Marcelo começa a trabalhar e conviver de perto com o 
centro político e institucional de Portugal. Aqui se inicia a sua carreira política. A entrada no Ministério das Finanças presidido por Salazar é o primeiro marco da sua capacidade de adaptação e de ambição política. Marcelo abandona o idealismo da política radical do IL e rapidamente se adapta à possibilidade de entrar na política real e participar na construção de uma ordem nova em Portugal, nacionalista, autoritária e corporativa.

Contudo, nesse período, o seu grande objetivo de carreira era a preparação do seu doutoramento, a que podemos acrescentar outro grande objetivo pessoal, que era o seu casamento. Assim, em 27 de outubro de 1930, Marcelo casa com Teresa de Barros, o que significa um importante marco social e de estabilidade pessoal para Marcelo, que sempre valorizou a sua vida familiar ${ }^{18}$. Depois de casar, em 17 de junho de 1931, Marcelo presta provas de doutoramento na Faculdade de Direito da Universidade de Lisboa, com a tese $A$ Depreciação da Moeda depois da Guerra. Aos 25 anos, torna-se o primeiro doutor da Faculdade de Direito de Lisboa na especialidade de Ciências Político-Económicas.

Ainda em 1931, Marcelo inicia uma colaboração com o Jornal do Comércio e das Colónias. Por intermédio do seu sogro, João de Barros, que conhecia o dono do antigo jornal, fundado em 1852, Marcelo começa a assinar artigos sobre a política nacional, o sistema colonial, a doutrina corporativista e assuntos de política internacional. O grande objetivo da sua coluna de opinião, intitulada "Notas Económicas e Financeiras", era a defesa das políticas económicas do ministro das finanças, Oliveira Salazar.

Estas "notas" foram, igualmente, um instrumento de acumulação de capital simbólico e consequente reconhecimento social e político, quer junto das elites políticas e sociais, quer, sobretudo, junto de Salazar. Com efeito, elas foram muito apreciadas pelo ministro, que Ihe teria confidenciado: "O senhor está-me prestando um grande serviço. Tenho verificado que os seus artigos são lidos nos meios económicos onde me interessava muito que penetrasse o esclarecimento da minha ação. E olhe que até eu passei a ser leitor assíduo do jornal!" (Caetano, 1977, p. 52).

Convém recordar que, nesta altura, Salazar ainda não tinha consolidado o seu poder autoritário. Institucionalmente era apenas o ministro das Finanças, e ainda era bastante criticado nos jornais da oposição. Isto significa que Marcelo prestou a Salazar um valioso apoio, que teria consequências. Marcelo será um dos poucos colaboradores de confiança que trabalharão com Salazar no seu projeto de edificação de um novo regime político e consequente elaboração de uma nova Constituição para Portugal.

Marcelo passa a reunir-se com Salazar em sua casa para a discussão da nova Constituição corporativa portuguesa. Estas reuniões na residência do ministro a propósito do projeto da Constituição resultaram numa importante aproximação política entre Marcelo e Salazar. Por várias vezes, almoçavam e jantavam juntos e a cumplicidade ideológica e política cimentou-se. Assim, após se tornar Presidente do Ministério, Salazar convida

\footnotetext{
18 Marcelo reconhece numa carta a Maria Prieto: "Procurei sempre que a vida pública e profissional não destruísse a minha vida de família (...), Mas tudo isso foi imperfeitamente conseguido porque não se pode abraçar o Mundo com os dois braços" (Prieto, 1992, p. 171).
} 
Marcelo para Membro da Junta Consultiva (JC) da recém-criada União Nacional (UN). Marcelo será, com 26 anos, o benjamim político da JC da UN e começará a alargar os seus contactos com figuras de primeiro plano do recém-criado regime autoritário português: o Estado Novo.

Marcelo torna-se um grande admirador das qualidades de liderança de Salazar e das suas certezas políticas e ideológicas. Apesar do seu passado radical e integralista, que o levou a considerar que o nacional-sindicalismo fascizante de Rolão Preto era um movimento que continha virtualidades e não deveria ser alvo de perseguições e violência ${ }^{19}$, na relativa luta política que se seguiu entre o o projeto político de Salazar e as ideias dos camisas azuis (Pinto, 1994), Marcelo opta decididamente pelo Estado Novo.

Por outro lado, as humildes origens sociais de Salazar, a sua capacidade de trabalho e suas qualidades carismáticas intelectuais serão caraterísticas que Marcelo, simultaneamente, aprecia e reconhece também como suas. Marcelo passa a ser um importante seguidor do líder do Estado Novo e um fervoroso defensor da revolução corporativa. Marcelo vai tornar-se um dos principais teóricos do corporativismo e um fiel apoiante de Salazar, embora também ouse criticá-lo.

Fruto desta aproximação política e reconhecendo-lhe mérito intelectual, em abril de 1933, Salazar convida Marcelo para ir para o governo como subsecretário de Estado das Corporações. Marcelo recusa o convite justificando que, nesse momento, o seu objetivo primordial é tornar-se professor na Faculdade de Direito de Lisboa. Esse é outro facto social importante no percurso político de Marcelo e reflete a sua capacidade de gerir a própria carreira estrategicamente. É um dos vários exemplos de decisão com base numa ambição política progressiva estratégica. Nesta fase, Marcelo preferiu não ir para o governo e consolidar o seu carisma intelectual como professor universitário.

Em junho, concorre e é aprovado no concurso de provas públicas para a vaga de professor. Em outubro inicia a sua carreira docente como regente das cadeiras de Direito Administrativo, Direito Internacional Público, Direito Corporativo e do Curso de Administração Colonial ${ }^{20}$. Esse feito é também um marco na sua trajetória de acumulação de capital social e poder simbólico, sobretudo num regime autoritário que nasceu com uma marca especial de liderança carismática e em que a notoriedade técnica e académica era muito relevante.

Em outubro de 1933, aceita o convite de Salazar e torna-se, com Albino dos Reis e António Carneiro Pacheco, membro da primeira Comissão Executiva da União Nacional, lugar que abandona no ano seguinte, em virtude de Salazar não o ter recebido

\footnotetext{
19 Marcelo escreve diretamente a Salazar a explicar isto (Antunes, 1993).

${ }^{20}$ Foi ainda, desde a sua fundação, em 1937, professor do Instituto do Serviço Social e, entre 1942 e 1945 , regente das cadeiras de Economia Política e Direito Industrial, no Instituto Superior Técnico. Ao longo da sua exemplar carreira académica, regeu ainda outras cadeiras de onde se destacam o Direito Municipal, o Direito Penal, a História do Direito Português, o Direito Constitucional e a Sociologia Geral. Esta sua qualidade de professor universitário também foi importante na sua estratégia de acumulação de capital social e poder simbólico.
} 
atempadamente nem ter dado seguimento às suas ideias sobre a reorganização da UN e sobre a metodologia da realização do seu primeiro congresso, e as relações pessoais de proximidade esfriam. Esta foi a primeira de várias discordâncias políticas que marcaram a relação entre ambos. Salazar assume que Marcelo não tem perfil para funcionário e que o seu espírito crítico e rebelde tem de ser temperado pela experiência e rodagem política. Marcelo, liberto dos espartilhos político-burocráticos do governo, dedica-se à consolidação do seu capital intelectual e torna-se um teórico do corporativismo.

Contudo, isso não diminui o seu espírito crítico, bem pelo contrário. Embora afastado do núcleo duro da decisão política do governo, Marcelo faz questão de se dirigir diretamente ao chefe de governo para sublinhar a sua visão corporativa e apontar os erros e desvios que a revolução corporativa estava a tomar. Durante os próximos dez anos, até ir para o governo em 1944, Marcelo irá corresponder-se com Salazar, muitas vezes apontando críticas diretas ao modo como o corporativismo estava a ser gerido em Portugal. Sobretudo a partir de 1942, as cartas dirigidas a Salazar aumentam o seu tom crítico ${ }^{21}$, o que também reflete a consolidação da autonomia intelectual e a acumulação de capital social e poder simbólico de Marcelo. Contudo, a sua lealdade política e admiração pela liderança de Salazar nunca são postas em causa. Salazar reconhece isso e nunca se esquece de contar com o contributo de Marcelo relativamente a questões técnicas ou de interesse intelectual. Por isso, convida-o, em 1935, para procurador à Câmara Corporativa, na qualidade de presidente da direção do Grémio dos Seguradores e, em 1936, apoia a sua eleição, por cooptação, para membro do Conselho do Império Colonial, cargo que ocupará até 1947.

Também irá convidá-lo, junto com Fezas Vital, para organizar e escrever o novo código administrativo, o que, apesar de algumas desconsiderações, não deixou de ser um importante reconhecimento do papel de "intelectual orgânico" de Marcelo. Em dezembro de 1935, é promulgado o Código Administrativo, que foi um dos principais contributos jurídicos de Marcelo para o Estado Novo. Em 1937, publica o seu Manual de Direito Administrativo - que conhecerá dez edições, todas revistas, a última de 1973.

Salazar não foi ingrato e, no dia 28 de maio, $11^{0}$ aniversário da Revolução, concede-Ihe a grã-cruz da Ordem Militar de Cristo. Em 1938, Marcelo faz uma viagem académica à Itália fascista para inaugurar a cátedra de Estudos Portugueses na Universidade de Roma e publica Problemas da Revolução Corporativa. De 1939 a 1940, é Presidente do Conselho de Administração da Caixa de Previdência do Ministério da Educação Nacional.

Em 1940, é nomeado Comissário Nacional da Mocidade Portuguesa, cargo que exercerá até entrar para o governo, em 1944. Aqui Marcelo vai ganhar projeção para além

\footnotetext{
${ }^{21}$ Por exemplo: "Tenho visto que parece ser condição de quem governa só ouvir metade da verdade e por isso me atrevo a vir dar-lhe uma informação (de entre tantas que às vezes me sinto tentado a dar-lhe!) (Marcelo, 1942, apud Antunes, 1993, p. 103). Ou ainda: "A falta de coordenação continua a parecer-me o maior defeito da nossa política. Cada Ministério, Direção-Geral, Inspeção, Junta ou Grémio tem uma orientação e às vezes tudo isto choca e contradiz (Marcelo, 1942, apud Antunes, 1993, p. 105).
} 
dos círculos académicos e políticos da capital. Será nesse cargo que iniciará a sua vocação política nacional no terreno, organizando e dirigindo iniciativas por todo o país. É nessa função que Marcelo aumenta o seu capital social e começa a ser reconhecido para além do círculo das elites. Marcelo irá modernizar a ação da Mocidade Portuguesa ${ }^{22}$ (MP), incutirIhe princípios mais escutistas e menos totalitários, sem nunca descurar o principal papel de doutrinação da juventude e de formação dos futuros dirigentes do Estado Novo.

Marcelo está convencido de que a MP é um importante pilar de educação ideológica dos princípios autoritários, nacionalistas e imperiais do corporativismo do Estado Novo. Também será nesta organização que Marcelo irá conhecer e recrutar muitos dos seus apoiantes e seguidores, aquilo que mais tarde se chamará de marcelismo (Mendes, 2020c).

Em 1943, publica Do Conselho Ultramarino ao Conselho do Império e faz, na Emissora Nacional, um discurso comemorativo do $11^{\circ}$ aniversário da tomada de posse de Salazar como Presidente do Conselho. Apesar do tom geral de elogio ao governo e às suas "virtudes políticas", Marcelo ousa afirmar que "Salazar tem defeitos como toda a gente" (Caetano, 1977, p. 157). Contudo, conclui afirmando que "a permanência de Salazar é, além de tudo mais, a garantia segura de que a Revolução continua" (Caetano, 1977, p. 161). Esta é outra caraterística que Marcelo vai cultivando na construção do seu poder simbólico e de acumulação de capital político da sua personalidade política: a capacidade de elogio crítico ao Estado Novo salazarista. Apesar do seu apoio político e pessoal a Salazar, Marcelo, não raras vezes, ousa ensaiar críticas ao líder do Estado Novo. Esta sua capacidade, como veremos, será decisiva para a acumulação do seu poder simbólico relativamente a uma hipotética liderança alternativa ao salazarismo.

\footnotetext{
22 A Mocidade Portuguesa (MP) foi uma organização nacional da juventude portuguesa criada pelo DecretoLei no 26 611, de 19 de maio de 1936, em cumprimento do disposto na Base XI da Lei no 1941, de 19 de abril de 1936. De influência inicial fascista e de carácter obrigatório, tinha como objetivo enquadrar ideologicamente a juventude portuguesa, nomeadamente: "estimular o desenvolvimento integrado da sua capacidade física, a formação do carácter e a devoção à Pátria, no sentimento da ordem, no gosto da disciplina e no culto do dever militar". Disponível em: <https://dre.pt/application/dir/pdf1sdip/1936/05/11600/05360547.pdf>. Acesso em: 16 maio 2020.

O seu primeiro comissário nacional foi Nobre Guedes, que se inspirou na juventude hitleriana. Com Marcelo, a MP afastou-se do seu carácter fascista e militarista, aproximando-se dos valores cristãos e escutistas.
} 
Figura 5

Escada da carreira política de Marcelo: do início até ao governo (1929-1944)

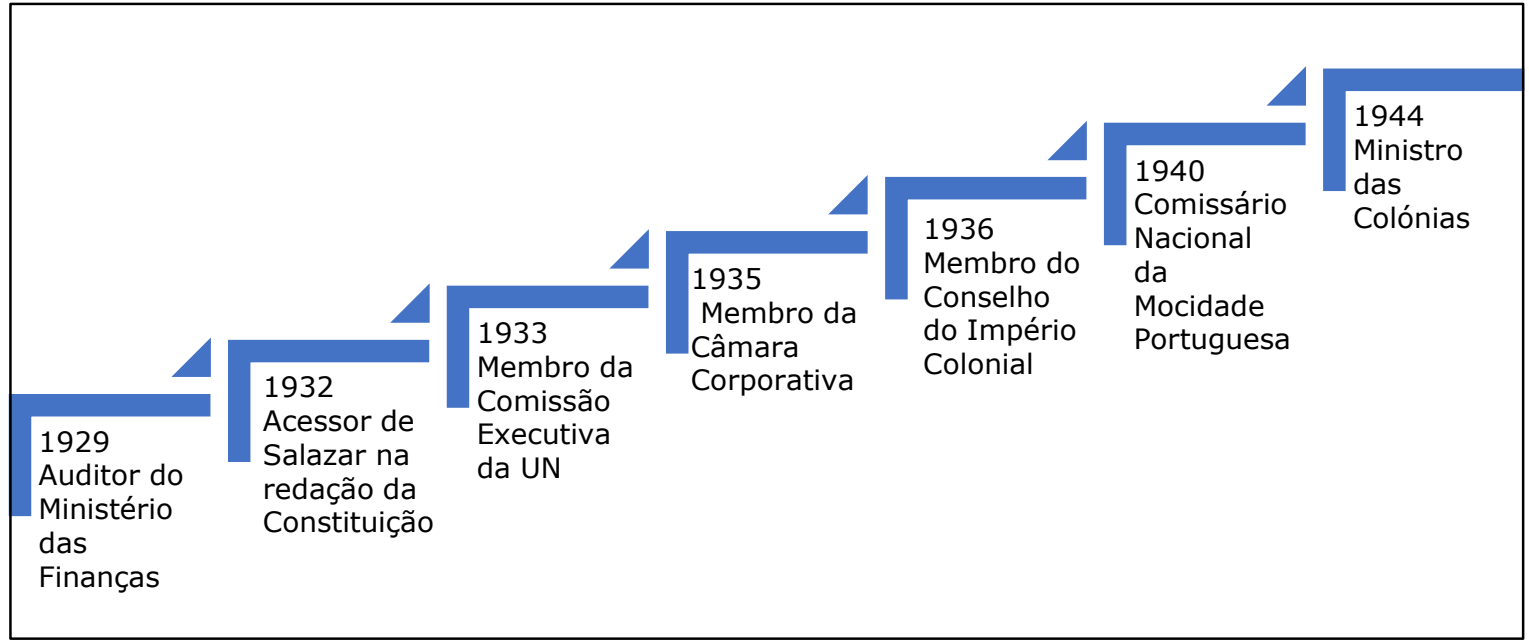

Fonte: Elaboração do autor.

\section{Passagens pelo governo e o início do marcelismo (1944-1958)}

Em 1944, Salazar convida Marcelo para o governo. Ele recusa a pasta da Justiça e propõe, sem sucesso, a criação de um Ministério da Assistência Social e de uma pasta da presidência, coordenadora da ação governativa. Contudo, acaba por aceitar a pasta das Colónias, tomando posse, no dia 6 de setembro de 1944, destas funções, que desempenhará até fevereiro de 1947.

O seu apoio à política do Estado Novo, ainda que por vezes crítico, o conduz ao governo aos 38 anos. Apesar do tom irreverente das cartas de Marcelo a Salazar (Antunes, 1993), que originou que fosse apelidado por alguns de "enfant terrible" (Marques, 2008) do Estado Novo, o Presidente do Conselho reconhece-Ihe mérito intelectual. Da mesma forma, Marcelo, apesar de não concordar com a gestão de alguns ministérios e até mesmo da forma de coordenação governamental, não consegue deixar de admirar as qualidades de liderança política e ideológica de Salazar.

É comum a tese de que Marcelo era encarado por Salazar como um "crítico" que convinha ter por perto (Rosas, 1996, 1998, 1999), não o querendo deixar solto, pelo que, apesar dos desencontros, Salazar estava constantemente a atraí-lo para o sistema de poder. A tese é verosímil, mas a questão parece mais complexa. Fruto de fatores pessoais e emocionais espelhados em muitos microepisódios que entrecruzaram a vida dos dois homens, e que vulgarmente escapam à leitura racionalista da história, existiu uma ligação de admiração intelectual mútua que, em última análise, foi o que permitiu construir uma relação de cumplicidade politicamente necessária e ultrapassar as desavenças políticas, 
MARCELO CAETANO E A SUA CIRCUNSTÂNCIA RUMO À LIDERANÇA: PODER SIMBÓLICO, AMBIÇÃO E ADAPTAÇÃO

bem como as relativamente diferentes visões do mundo que defendiam (Mendes, 2020a, 2020c).

Resta enfatizar que esta relação de admiração política foi enfraquecendo à medida que o tempo foi passando. Marcelo amadureceu, autonomizou-se política e ideologicamente e começou a distanciar-se do conservadorismo rural salazarista, a ponto de, na sua última fase, ter de se confrontar com a necessidade política de extinguir o mito da recuperação de Salazar (Mendes, 2020a).

Como ministro das Colónias, realiza, em junho de 1945, uma viagem de cinco meses por São Tomé, Angola e Moçambique, onde novamente solidifica a sua visão africanista, nomeadamente quanto à importância de Portugal investir e apostar no desenvolvimento destas colónias. No seu mandato, são instituídas várias medidas relevantes das quais podemos destacar: o lançamento da agência noticiosa ultramarina Lusitânia; a criação do Fundo de Povoamento; a revisão do Ato Colonial; a criação dos Serviços de Urbanismo do Ultramar; a reforma da Junta de Investigação do Ultramar e da Escola Colonial, que passa a ser uma escola superior; a instituição do Fundo de Colonização; a criação da Hidroelétrica do Revuè, em Moçambique; e o lançamento da ligação aérea imperial da TAP entre Lisboa, Luanda e Lourenço Marques (Araújo, 2004).

Para além destas medidas reformistas, a grande oportunidade política de Marcelo como ministro será a de consolidar o seu papel de homem público com uma visão mais modernizante do Estado Novo. Sobretudo a partir de 1946, Marcelo Caetano irá afirmarse como líder de uma ala dissidente e reformista do regime. Todavia, convém evitar confusões. A sua crítica não é às ideias autoritárias e corporativas do Estado Novo, mas sim ao amolecimento da revolução corporativa, à desmobilização e ao situacionismo de alguns sectores que, em sua opinião, não acompanham as exigências da construção de um Estado Novo em Portugal (Caetano, 1977; Antunes, 1993).

Com efeito, de um ponto de vista teórico e de doutrinação sobre a necessidade de se instaurar uma ordem nova, que apagasse a decadência político-parlamentar da República, Marcelo possuía um fervor ideológico corporativista inigualável. Aliás, as primeiras críticas de Marcelo a Salazar prendiam-se com divergências conceptuais e políticas sobre o alcance da revolução corporativa a efetuar em Portugal. São vários os episódios em que Salazar, pragmaticamente, teve de anular a velocidade dos projetos marcelistas de "verdadeiramente" corporativizar o regime (Antunes, 1993; Torgal, 2009). Portanto, nesse período, o que Marcelo defende é mais e melhor Estado Novo, não menos (Mendes, 2020a, 2021a).

Todavia, fruto da sua curiosidade intelectual e espírito académico, Marcelo era mais aberto a novas ideias, era mais moderno e cosmopolita do que Salazar e foi, paulatinamente, aderindo às correntes desenvolvimentistas e tecnocráticas da gestão governativa. Embora seja possível descortinar vários pontos comuns no discurso e prática política de Salazar e Marcelo, designadamente a pretensa administração técnica e não 
política dos interesses nacionais, a ausência de cultura democrática e a utilização da violência legal, a verdade é que eram homens diferentes.

Salazar era um conservador tradicional, nacionalista, católico, rural e ideologicamente menos sofisticado do que Marcelo. Salazar era um animal político realista clássico, um manobrador exímio com um talento raro para se perpetuar no poder, sabia o que queria e tinha as suas certezas relativamente inamovíveis. Era um doutrinador prático. Marcelo era de outra espécie; era, sobretudo, um intelectual político, embora também procurasse ser um doutrinador prático, era menos estático e tentava adaptar o seu pensamento às novas ideias e problemas sociais e políticos (Mendes, 2020a, 2021a). Uma das melhores caraterizações de Marcelo partiu do próprio Salazar. Com efeito, Salazar teria confidenciado a Franco Nogueira a seguinte análise sobre Marcelo: "Um belo espírito. Ideias liberais, em princípio, e muito impressionável. Segue sempre a corrente dominante em cada momento, acredita sempre na última verdade que lhe é assoprada. Ah! Mas é um belo espírito" (Nogueira, 1987, p. 37-38).

Contudo, o facto de ser um académico e intelectual não deve ser confundido com uma visão abstrata e distante das questões da governação e ação política, bem pelo contrário. Marcelo sempre procurou na ciência uma ferramenta útil para a sua atividade política. Desse modo, o seu estudo académico foi sempre dominado por uma visão prática e útil. Por isso, aliás, Marcelo foi um dos precursores do estudo da Ciência Política em Portugal e sempre defendeu que a Universidade, designadamente a sua Faculdade de Direito, deveria formar elites preparadas para a governação. Ele próprio assumiu que nunca sentiu dificuldades em conciliar o seu espírito académico com o exercício do poder. Quando, a esse propósito, Marcelo foi questionado numa célebre entrevista, respondeu o seguinte:

Esse problema nunca se me pôs porque nunca fui um jurista abstracto (...) Desde os tempos de estudante que fui militante político. Foi ainda a preocupação do concreto que me levou ao estudo da Economia e, mais tarde, ao Direito Administrativo, a fim de estudar como se processa concretamente o poder político na estrutura viva de uma sociedade. Também o gosto que tenho pela História se radica nessa preocupação (Baptista, 1973, p. 58).

No dia 11 de novembro de 1946, Marcelo faz o discurso de encerramento da I Conferência da União Nacional (UN). Pela primeira vez, de forma pública, Marcelo refere a existência de tendências conservadoras e reformistas dentro do Estado Novo. A verdade é que, na remodelação governamental de fevereiro 1947 e dos corpos dirigentes da UN, em março, o marcelismo começa a ganhar vida. Aqui já é visível a inclusão de vários "amigos" do círculo de Marcelo Caetano em cargos relevantes.

Nesse quadro, a partir do dia 4 de março, Marcelo passará a presidir à Comissão Executiva da UN onde, novamente, procurará renovar o Estado Novo e alargar a sua influência política, nomeadamente procurando integrar, no regime, uma nova geração de 
MARCELO CAETANO E A SUA CIRCUNSTÂNCIA RUMO À LIDERANÇA: PODER SIMBÓLICO, AMBIÇÃO E ADAPTAÇÃO

universitários e profissionais liberais. Todavia, as promessas de reforma e abertura discutidas com Salazar não têm efeito. Pelo contrário, surgirá uma onda de ataques repressivos sobre a oposição e vão se acentuar as resistências à redinamização e flexibilização da UN. O episódio mais marcante será a intervenção da polícia na Faculdade de Medicina de Lisboa e a demissão compulsiva de alguns professores universitários. Marcelo, desiludido, reage pedindo a Salazar a sua exoneração do cargo de Presidente da Comissão Executiva da União Nacional. Decisão que, para minimizar estragos políticos, será protelada para depois das eleições para a presidência da República de fevereiro de 1949.

Em janeiro de 1948, nasce o Centro de Ação Popular, que congrega jovens próximos de Marcelo e que será mais um ponto de apoio do marcelismo. Em abril, Marcelo é eleito administrador do Banco Nacional Ultramarino, função que desempenhará até junho de 1951.

Em novembro de 1949, aceita o convite de Salazar para ser presidente da Câmara Corporativa. Aqui, novamente se fará sentir o pendor reformista de Marcelo, que reorganiza os serviços e o modo de funcionamento da Câmara, amplia as suas instalações, e inicia a publicação dos Pareceres da Câmara Corporativa e do jornal oficial, Actas da Câmara Corporativa. Apesar de não ser um cargo de poder governamental, será nele que Marcelo irá solidificar definitivamente uma corrente marcelista, alargando a sua rede de amizades, fidelidades e influência entre uma nova geração de quadros ligados às atividades económicas e corporativas.

Estas novas elites são fruto da progressiva industrialização, urbanização e terciarização de Portugal, iniciada nos anos 1950, que começará a mudar a conjuntura económica e social do Portugal do início do século (Mendes, 2013, 2020c). Marcelo começa a colocar no aparelho de Estado jovens engenheiros industrialistas, "técnicos" defensores de reformas na agricultura e educação, desenvolvendo uma rede de contactos e influência política que servirá de elo entre dirigentes ligados às colónias, à banca e à própria UN. Nasce um "quase-partido" informal reformista e modernizante dentro do Estado Novo, que tem como epicentro e principal referência política Marcelo Caetano (Rosas, 1996, 1998, 1999).

É já nesse contexto que se deve compreender o papel de Marcelo no III Congresso da União Nacional, com o seu famoso "discurso de Coimbra". Ou seja, quando, após a morte do presidente Carmona, se reacende a questão monárquica e se coloca, pela primeira vez, a hipótese da sucessão de Salazar. Nesse momento, Caetano opõe-se a uma manobra formalmente restauracionista da Monarquia e novamente assume o papel de defensor do regime do Estado Novo (Rosas, 1999).

Em novembro de 1951, Marcelo publica Tradições, Princípios e Métodos da Colonização Portuguesa. No ano seguinte, é nomeado membro vitalício do Conselho de Estado e, em 1953, torna-se vice-presidente do Conselho Ultramarino. Na remodelação governamental de 1955, Marcelo entra novamente para o governo, agora como ministro 
da Presidência. Toma posse em julho e, em outubro, promove o decreto-lei que autoriza o governo a concessionar um serviço público de televisão, é a génese da Rádio e Televisão de Portugal (RTP). Marcelo foi o primeiro membro do governo a utilizar a RTP para se dirigir aos portugueses.

No ano seguinte, publica A Constituição de 1933, Estudo de Direito Político. Em maio de 1956, discursa no Congresso de Industriais e Economistas, na inauguração da Feira Internacional de Lisboa (FIL), onde expõe o seu pensamento reformista. Em julho, promulga o decreto-lei que institui a Fundação Calouste Gulbenkian e aprova os seus estatutos resultantes da participação de Salazar, Marcelo e Azeredo Perdigão.

Enquanto ministro da Presidência, dirigiu o Secretariado Nacional de Informação (SNI); foi responsável pela preparação do II Plano de Fomento; representou Portugal nos Conselhos de Ministros da Organização Económica de Cooperação Europeia (Oece) e da Organização do Tratado do Atlântico Norte (Nato) e acompanhou o processo de adesão de Portugal à Associação Europeia de Comércio Livre (EFTA). Ainda, entre 26 de dezembro e 11 de fevereiro, acumula, interinamente, a pasta dos Negócios Estrangeiros.

Na sua passagem pela pasta da Presidência, Marcelo ganha o protagonismo de um putativo sucessor de Salazar. Com efeito, no rescaldo da crise de 1951, Salazar recompensa Marcelo com a pasta que este sempre almejou e deu um sinal claro de que Marcelo passaria a ser o seu braço direito no governo. Todavia, a progressiva convergência de ideias com o novo Presidente da República, o general Craveiro Lopes, e a hipótese posta a circular de esse poder vir a substituir Salazar por Caetano após uma eventual reeleição em 1958 elevam até ao limite as lutas surdas entre reformistas ("marcelistas") e conservadores, também designados "costistas" (corrente que girava em torno do ministro da Defesa Santos Costa) (Rosas, 1999; Castilho, 2012; Leitão, 2014).

Salazar reage com a sua habitual capacidade de sobrevivência. Afasta Craveiro Lopes da corrida presidencial de 1958 e concentra todos os seus esforços no combate ao fenómeno oposicionista liderado por Humberto Delgado nas eleições de maio ${ }^{23}$. Acabada a luta presidencial, eleito o seu candidato, Salazar, de forma salomónica, demite do governo Marcelo Caetano e Santos Costa, promovendo, em 14 de agosto de 1958, nova remodelação governamental (Rosas, 1998). Marcelo solicita, então, uma audiência ao Presidente da República, Américo Tomás, em que apresenta o seu pedido de renúncia ao cargo vitalício de membro do Conselho de Estado (Castilho, 2012; Leitão, 2104). Esta renúncia nunca foi oficialmente publicada. Contudo, Marcelo nunca mais participará nessas reuniões até 1968, altura em que regressa para a discussão sobre a (sua) sucessão de Salazar (Mendes, 2020a, 2021a).

\footnotetext{
23 Em julho de 1958, em reunião do Conselho de Estado sobre os candidatos à presidência da República, Marcelo rejeita ambos os candidatos da oposição: Humberto Delgado e Arlindo Vicente.
} 


\section{Afastamento da vida política, a Reitoria e o regresso ao palco político (1958-1968)}

Com a saída atribulada do governo, Marcelo irá distanciar-se da atividade política e retornar à vida académica, sendo nomeado reitor da Universidade de Lisboa (UL) em janeiro de 1959. Aqui irá ter um papel de reorganização administrativa e dos serviços académicos da nova reitoria e da cidade universitária. Todavia, o seu mandato ficará marcado pela crise académica provocada pela proibição do Dia do Estudante, na qual irá ter um papel de defensor da autonomia universitária. Apresenta a sua demissão em 1962, em protesto contra a ação repressiva da polícia de choque sobre os estudantes. Mais do que a defesa da possibilidade da realização do Dia do Estudante, Marcelo não tolera a posição do governo de sabotagem ao seu prestígio e autoridade como reitor da UL. Envia uma cópia da sua carta de demissão a Salazar, acompanhada de um cartão no qual afirma que, com o abandono das suas funções de reitor da UL, "corta os últimos laços com a vida pública" (Antunes, 1993, p. 399).

A partir daqui, Marcelo Caetano inicia uma relativa travessia no deserto (Martinho, 2016). Saiu contrariado da Reitoria e em rutura com o governo. Apesar da sua ambição política não ter desaparecido, está decidido a não aceitar mais qualquer responsabilidade política no regime. Assiste à distância ao falhanço do golpe de Júlio Botelho Moniz em abril de 1961, embora fosse o eventual chefe do governo a indigitar pelos conspiradores. No rescaldo da "abrilada", recusa o convite de Salazar para o Ministério da Economia. Concentra-se nas suas aulas, na investigação e publicação, e no seu papel de jurisconsulto, sendo os seus pareceres jurídicos muito procurados por alguns dos maiores grupos económicos portugueses. Em 1963, é escolhido para professor da Faculdade Internacional de Direito Comparado e eleito vice-presidente do seu conselho.

No entanto, a sua saída da vida política ativa não significou o fim do marcelismo nem um corte completo com a situação política nesse período final do salazarismo. $\mathrm{Na}$ verdade, vários marcelistas como, por exemplo, Baltasar Rebelo de Sousa, Silva Pinto, Dias Rosas, César Moreira Baptista, Camilo de Mendonça, Melo e Castro continuaram a desenvolver as suas carreiras no governo ou na administração do Estado Novo. Por outro lado, as suas posições, mesmo como académico especialista, continuaram a ser importantes e a ter ecos políticos no regime, como foi o caso do seu memorial para o Conselho Ultramarino, em 1962, no qual defende uma solução federal para o problema colonial, contrariando as teses integracionistas dominantes.

Desse modo, Marcelo continua a se reunir com o seu "núcleo duro", primeiro na sua casa do Linhó e, depois, na tertúlia política do restaurante da linha do Estoril, Choupana, e a alimentar a hipótese, cada vez mais provável, de suceder a Salazar como presidente do Conselho. Prova de que, apesar do afastamento de Marcelo da vida política ativa, o marcelismo continuava a fazer o seu curso era a presença de vários marcelistas 
na última remodelação governamental efetuada ainda com Salazar na presidência do Conselho, em agosto de $1968^{24}$.

Após a constatação da irreversibilidade da doença de Salazar, o Conselho de Estado reúne-se no dia seguinte, a 17 de setembro de 1968. Marcelo, após dez anos ausente, com surpresa de alguns, comparece. A discussão centra-se em torno de duas hipóteses: a sucessão interina, que recebe o apoio da maioria, ou a nomeação de um novo presidente do Conselho. Na sua intervenção, Marcelo diz compreender o sentimento de respeito dos conselheiros pela memória de Salazar, mas alerta para a necessidade de nomeação imediata do seu sucessor "para assegurar a normalidade da vida do país e manter o regular funcionamento das instituições" (Thomaz, 1983, p. 295).

Na reunião, fica estabelecido que caberia ao Presidente da República a decisão de nomear o novo Presidente do Conselho. No fim da reunião, Américo Tomás afirma que tomará a sua decisão após ouvir todos os conselheiros e outras individualidades em audiências privadas. Nos quatro dias seguintes, ouve mais de 40 personalidades sobre os hipotéticos sucessores. Daqui resulta uma lista onde constavam os nomes de Marcelo Caetano, Supico Pinto, Franco Nogueira, Adriano Moreira, Antunes Varela, Gomes de Araújo e Correia de Oliveira. No dia 24, Américo chama Marcelo Caetano a Belém e informa-o de que mais de $90 \%$ das personalidades ouvidas indicaram o seu nome e, que, nesse quadro, o convidava para chefe do governo. A acumulação de poder simbólico de Marcelo dava finalmente os seus frutos, este confirma-se como o sucessor natural.

Todavia, o Presidente da República faz depender a aceitação do convite de várias condições: assumir o cargo interinamente, enquanto Salazar fosse vivo; manter a maioria dos ministros no recém-nomeado governo e, sobretudo, continuar com a política ultramarina e o esforço de guerra. Marcelo chama a atenção ao Presidente de que, constitucionalmente, a solução interina não era possível. Américo Tomás anui à lógica jurídica de Marcelo e este aceita a lógica política da continuidade do governo, chegando a um compromisso. Quanto à questão essencial, o ultramar, a resposta de Marcelo foi que a sua ideia seria a de aproveitar as eleições de 1969 para auscultar o país sobre o problema ultramarino. Marcelo recorda esse ponto crítico da conversa da seguinte forma:

Se assumisse o governo, procuraria que as eleições gerais a realizar em 1969 fossem o mais corretas possível para que, se as ganhasse, ganhasse bem. Seria a oportunidade de deixar a nação exprimir o seu ponto de vista quanto ao ultramar. Se a votação fosse favorável à política de defesa que estava em curso muito bem... Se não...

24 Esta remodelação operou as seguintes entradas ministeriais: Gonçalves Rapazote no Interior; José Hermano Saraiva na Educação; Dias Rosas nas Finanças; Bettencourt Rodrigues no Exército; Pereira Crespo na Marinha; Jesus dos Santos na Saúde; e, em 28 de agosto de 1968, Canto Moniz nas Comunicações (Mendes, 2020a). 
- Se não, as Forças Armadas intervirão, interrompeu o Presidente da República (Caetano, 1974, p. 14).

Marcelo escusa-se a relatar a continuação da sua conversa com Américo Tomás, mas é plausível que a reunião não tenha acabado com a interrupção citada. Contudo, é possível interpretarmos os factos da sua narrativa da seguinte forma. Primeiro, Marcelo parece ter ideias claras sobre a sucessão de Salazar e planos para o "day after", comprovando a sua ambição política de liderar o governo de Portugal. Segundo, Marcelo, desde o início, assume a sua dependência política relativamente ao Presidente da República, invertendo a anterior lógica política do Estado Novo, em que, ultrapassando a lei constitucional, era, na prática, o presidente que dependia do chefe de governo. Esta anuência política ao Presidente da República pode ter sido taticamente correta no momento da sucessão, pois possibilitou a Marcelo, finalmente, concretizar a sua grande ambição de liderar os destinos de Portugal. Contudo, irá revelar-se um obstáculo estratégico de médio prazo, pois era contraditória com os objetivos de renovação do Estado Novo. 
Figura 6

Carreira política e acumulação de poder simbólico (CS+CP) rumo à liderança

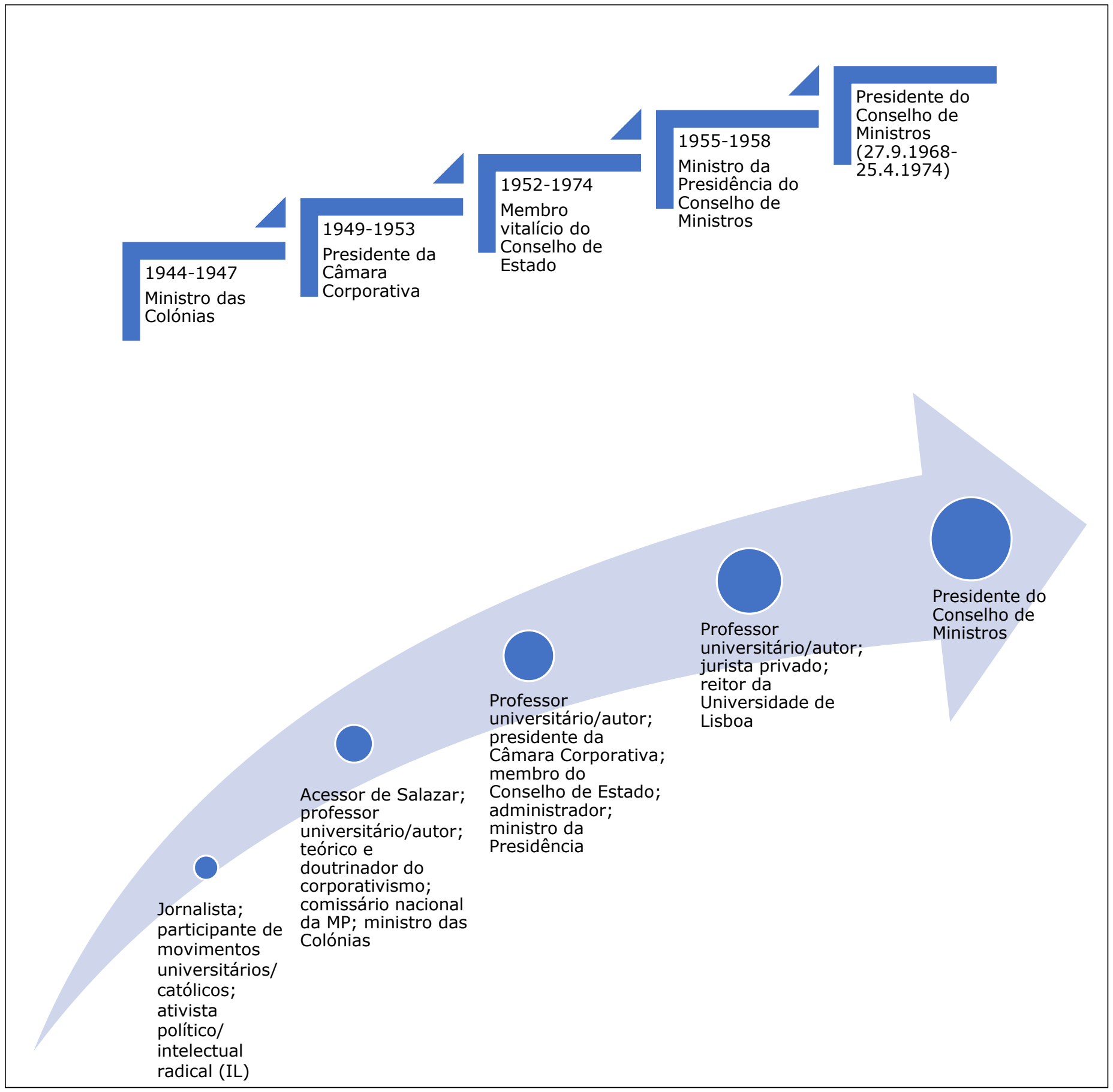

Fonte: Elaboração do autor. 
MARCELO CAETANO E A SUA CIRCUNSTÂNCIA RUMO À LIDERANÇA: PODER SIMBÓLICO, AMBIÇÃO E ADAPTAÇÃO

\section{Conclusão}

Depois de apresentarmos os principais marcos, e as suas circunstâncias, do trajeto de Marcelo Caetano até 1968, estamos agora em condições de apontar as seguintes conclusões.

Primeiro, como este artigo demonstra, o percurso político de Marcelo até chegar à liderança do Estado Novo é extenso, aparentemente linear, mas com diferentes ciclos circunstanciais e históricos. Assim, podemos identificar quatro ciclos ao longo desse percurso: primeiro, a universidade, o jornalismo e a política radical (1922-1929); segundo, a maturidade, a política real e a assunção do corporativismo do Estado Novo (1929-1944); terceiro, as passagens pelo governo e o início do marcelismo (1944-1958); quarto, o afastamento da vida política, a Reitoria e o regresso ao palco político (1958-1968).

Em segundo lugar, a carreira política modelar de Marcelo explica-se pela sua capacidade de ambição política progressiva e estratégica. Como demonstramos, o seu percurso político é guiado por tal ambição e pela necessidade de ir acumulando poder simbólico que conseguisse demonstrar a sua capacidade de se assumir como o natural sucessor de Salazar.

Por outro lado, de um ponto de vista estritamente ideológico, é possível dizer que existe um jovem Marcelo sob influência de ideias católicas, conservadoras e integralistas, que corresponde ao primeiro ciclo do seu percurso, muito marcado pelo ambiente político e ideacional da época e pelo seu idealismo radical. Esse fervor ideológico integralista e radical irá ser substituído pela sua aderência à "revolução corporativa" do Estado Novo.

Muito persuadido pelas ideias e práticas de Salazar, Marcelo passa a defender o corporativismo do Estado Novo e a assumir a liderança patriarcal de Salazar para Portugal. Aqui é possível dizer que estamos perante um Marcelo adulto, influenciado pelas ideias corporativas e financeiras do salazarismo, bem como pela sua aproximação à política real. Esse período corresponde ao segundo ciclo, embora também seja possível enquadrá-lo na primeira parte do terceiro ciclo do seu percurso, até sensivelmente ao início da década de 1950.

Gradualmente, Marcelo vai, então, começar a assumir ideias desenvolvimentistas e tecnocráticas, que, embora compatíveis com o Estado Novo, começam a desenhar uma possibilidade de dissidência moderna, urbana, tecnocrática e menos autárcica face às ideias originais do ruralismo conservador, nacionalista e católico do salazarismo. Nesse período, sobretudo a partir da década 1950 e da sua passagem pela pasta da presidência, Marcelo começa a solidificar uma visão mais moderna e própria do seu projeto de aperfeiçoamento liberalizante do Estado Novo. Esta é fase do Marcelo maduro, que inicia um processo de autonomização e diferenciação do modelo salazarista e dá origem ao marcelismo, como uma corrente política com um projeto relativamente alternativo ao salazarismo. Tal fase do Marcelo, madura e autónoma, integra a última parte do terceiro 
ciclo e o quarto ciclo, em que Marcelo se distancia da governação, mas nunca se desliga da vida política portuguesa, mantendo ligações indiretas com o governo.

De qualquer modo, apesar destas diferentes fases, é possível identificar algumas constantes que caracterizam a sua personalidade ao longo do seu percurso político até tornar-se chefe de governo: grande espírito de trabalho; curiosidade intelectual e académica; forte ambição política e de ascensão social e profissional; desejo de liderança e de reconhecimento político.

Em termos comparativos, embora partilhe com Salazar os traços de liderança autoritária e técnica, a importância da ordem corporativa e de controlo político e um anticomunismo primário, Marcelo é menos paroquial, mais gregário e tem mais experiência internacional. Contrariamente a Salazar, Marcelo não foi apenas académico e governante na torre de babel. Para além de académico e governante, Marcelo foi igualmente um homem de família e de amizades, bem como um administrador e jurista no sector privado, gestor de empresas públicas e autor de uma vasta bibliografia, jurídica, política e histórica. Toda esta circunstância social, que extravasa a vida governativa e política, distingue Marcelo de Salazar e determina uma diferente visão do mundo. Distintamente de Salazar, Marcelo estava mais imerso no mundo social real, o que originou uma maior socialização ideacional e adaptabilidade à evolução política e social do mundo ${ }^{25}$. Esta sua dimensão social, conjugada com a sua qualidade de académico intelectual, torna Marcelo mais aberto e adaptável a evolução das ideias e práticas do Zeitgheist, o que não é o mesmo que dizer que Marcelo não tinha igualmente características autoritárias e dogmáticas como Salazar. Contudo, Marcelo era socialmente mais sofisticado e ideacionalmente mais adaptável.

Esta sua adaptabilidade foi um dos trunfos da sua longevidade no Estado Novo e foi o que permitiu que Marcelo se perfilasse, em simultâneo, quer como líder delfimsucessor, quer como líder de uma corrente alternativa ao salazarismo. O problema, como se veio a verificar, é que as duas coisas não eram exatamente compatíveis.

\section{Referências bibliográficas}

ANTUNES, J. F. Salazar e Caetano: cartas secretas - 1932-1968. Lisboa: Círculo de Leitores, 1993.

Araújo, A. Caetano, Marcelo José das Neves. In: Cruz, M. B.; PINTo, A. C. (dir.). Dicionário biográfico parlamentar: 1935-1974, vol. I. Lisboa: Assembleia da República/ICS, p. 300-305, 2004.

\footnotetext{
${ }^{25}$ Isto não significa que, de um ponto de vista estritamente pragmático e operacional de um líder político chegar e manter-se no poder -, Marcelo tivesse mais sucesso político que Salazar. Foi o contrário (Mendes, 2020c). Salazar é um caso raro de longevidade política no poder - 38 anos -, enquanto Marcelo só conseguiu estar seis anos como líder do governo de Portugal. Como sublinhamos, Marcelo, ao contrário de Salazar, não conseguiu impor uma liderança carismática hegemónica em Portugal (Mendes, 2013, 2019a). Todavia, é preciso destacar os diferentes contextos históricos na afirmação das respetivas lideranças. Isto é, os contextos de afirmação do "triângulo carismático" (Pinto e Larsen, 2006, p. 251) para Salazar e Caetano foram bastante diferenciados. Perceber isto é fundamental e comprova um dos principais argumentos deste artigo: o sucesso de uma liderança política é sempre explicado pela relação entre as qualidades individuais e agenciais dos líderes e as circunstâncias e contextos históricos e sociais das estruturas em que os líderes se movem.
} 
ARIStóteles. Ética a Nicômaco: seleção de textos de José Américo Motta Pessanha. $4^{a}$ ed. São Paulo: Nova Cultural, 1991.

BAIÔA, M. Partidos e sistema partidário na crise do liberalismo em Portugal e Espanha nos anos vinte. In: BAIÔA, M. (dir.). Elites e poder: a crise do sistema liberal em Portugal e Espanha (19181931). Évora: Cidehus, 2004.

BAPTISTA, A. A. Conversas com Marcello Caetano. Lisboa: Moraes editores, 1973.

BERGER P. S.; LUCKMANN, T. The social construction of reality: a treatise in the sociology of knowledge. New York: Anchor Books, 1966.

BLACK, G. "A theory of political ambition: career choices and the role of structural incentives". American Political Science Review, vol. 66, p. 144-159, 1972.

BOURDIEU, P. "Le capital social: notes provisoires". Actes de la Recherche en Sciences Sociales, vol. 31, p. 2-3, 1980.

. Sociologia. Org. Renato Ortiz. São Paulo: Ática, 1983.

. The forms of capital. In: RichaRDSON, J. G. (org.). Handbook of theory and research for the sociology of education. New York: Greenwood, p. 241-258, 1985.

. O poder simbólico. Lisboa: Difel, 1989.

CAetAno, M. Depoimento. Rio de Janeiro: Record, 1974.

. Minhas memórias de Salazar. Lisboa: Verbo, 1977.

CASTilho, J. T. Marcelo Caetano: uma biografia política. Coimbra: Almedina, 2012.

CRUZ, M. B. O Estado Novo e a igreja católica. Lisboa: Bizâncio, 1998.

EULAU, H. The legislative career. In: WAHLKE, J C., et al. (eds.). The legislative system: explorations in legislative behavior. New York: John Wiley and Sons, p. 272-280, 1962.

Fowler, L.; MCCLURE, R. Political ambition: who decides to run for Congress. New Haven: Yale University Press, 1989.

FRANCIS, W. L.; KENNY, L. W. Up the political ladder: career paths in U.S. politics. Thousand Oaks: Sage, 2000.

GidDENS, A. The constitution of society: outline of the theory of structuration. Berkeley, LA: University of California Press, 1984.

HeLfer, A. Socrates and Alcibiades: Plato's drama of political ambition and philosophy. Philadelphia: University of Pennsylvania Press, 2017.

HERRICK, R.; MOORE, M. K. "Political ambition's effects on legislative behavior: Schlesinger's typology reconsidered and revised". Journal of Politics, vol. 55, p. 765-776, 1983.

LEITÃo, L. M. Marcello Caetano: um destino. Lisboa: Quetzal Editores, 2014.

MAESTAS, C. D., et al. "When to risk it? Institutions, ambitions, and the decision to run for the U.S. house". American Political Science Review, vol. 100, p. 195-208, 2006.

MARQUES, P. Marcello Caetano: ideólogo ou "enfant térrible" do regime? 1906-1980. Lisboa: A. M. Pereira/Público, 2008. 
MARTINHO, F. P. O Estado Novo e a historiografia portuguesa: sobre a questão do fascismo. In: FReIRE, A; Nunes, J. P (orgs.). Historiografias portuguesa e brasileira no século XX. Coimbra: Ed. Universidade de Coimbra, p. 111-146, 2013.

. Marcello Caetano: uma biografia, 1906-1980. Lisboa: Objectiva, 2016.

MARTINS, F. Integralismo lusitano e política nacional: as metamorfoses e os desafios da década de 1920. In: BAIÔA, M. (dir.). Elites e poder: a crise do sistema liberal em Portugal e Espanha (19181931). Évora: Cidehus, 2004.

MARX, K. The Eighteenth Brumaire of Louis Bonaparte. In: MCLELLAN, D. (ed.). Karl Marx: selected writings. London: Oxford University Press, 2010.

Mendes, P. E. "A (re)invenção das relações internacionais na viragem do século: o desafio do construtivismo". Relações Internacionais, vol. 36, p. 105-118, 2012. 107-121, 2013.

"A questão europeia no marcelismo: o debate geracional". População e Sociedade. 21, p.

. "Identidade, ideias e normas na construção dos interesses em política externa: o caso português". Análise Social, 227, LIII (2), p. 458-487, 2018. Disponível em:

<https://doi.org/10.31447/as00032573.2018227.09>. Acesso em: 16 maio 2020.

- "História, discurso político e liderança em Portugal: um diálogo interpretativo entre presente e passado à luz do Diário de Governo". População e Sociedade, no 32, p. 182-203, 2019a.

"As teorias principais das relações internacionais: uma avaliação do progresso da disciplina". Relações Internacionais, no 61, p. 95-122, 2019b. Disponível em:

<https://doi.org/10.23906/ri2019.61a0>. Acesso em: 16 maio 2020.

"The birth of International Relations as a social science: a comparative analysis of the Anglo-American world and continental Europe". Austral: Journal of Strategy \& International Relations. vol. 8, no 16, p.19-50, 2019c. Disponível em:

<https://doi.org/10.22456/2238-6912.89031>. Acesso em: 16 maio 2020.

Lisboa: INCM, 2020a.

. Marcelo Caetano. In: SousA, F.; MeIReles, C. (coords.). Os primeiros ministros de Portugal.

"Perceções e imagens na política externa do Estado Novo: a importância do triângulo

identitário". Dados, vol. 63, no 3: e20190067, 2020b. Disponível em:

<https://doi.org/10.1590/dados.2020.63.3.214>. Acesso em: 16 maio 2020.

. "Os dilemas da renovação na continuidade e o legado de Marcello Caetano: do outono ao inverno". Tempo e Argumento, vol. 12, no 29, e0205: p. 1-35, 2020c. Disponível em:

<https://doi.org/10.5965/2175180312292020e0205>. Acesso em: 16 maio 2020.

"R(r)elações I(i)nternacionais, realismo e análise da política externa (APE): contextualizando a invenção da APE". Estudos Internacionais, vol. 8 no 1, p. 64-88, 2020 d. Disponível em: <https://doi.org/10.5752/P.2317-773X.2020v8n1p64-88>. Acesso em: 16 maio 2020.

. "Marcelo Caetano, do idealismo da juventude à política real (1906-1944): uma teorização histórico-sociológica". Tempo Social, vol. 33, no 1, p. 121-144, 2021a. Disponível em: <https://doi.org/10.11606/0103-2070.ts.2021.170969>. Acesso em: 16 maio 2020.

. "Os eternos movimentos (in)disciplinares entre a história e as relações internacionais: a importância do pensamento histórico". História da Historiografia, vol. 15, 2021 b. 
MARCELO CAETANO E A SUA CIRCUNSTÂNCIA RUMO À LIDERANÇA: PODER SIMBÓLICO, AMBIÇÃO E ADAPTAÇÃO

Menezes, F. R. Salazar: uma biografia política. Alfragide: Dom Quixote, 2014.

MessiAs, G. M. G. "Carreira e ambição política dos vereadores de Salvador (1997-2012)". Revista de Sociologia e Política, vol. 27, no 72, 2019.

Miguel, L. F. "Capital político e carreira eleitoral: algumas variáveis na eleição para o Congresso brasileiro". Revista de Sociologia e Política, no 20, p. 115-134, 2003.

Nogueira, F. Um político confessa-se: Diário 1960-1968. Porto: Civilização, 1987.

ONUF, N. World of our making: rules and rule in social theory and international relations. Columbia: University of South Carolina Press, 1989.

ORTEgA y GASSET, J. Meditações do Quixote (1914). São Paulo: Ibero-Americano, 1967.

Pinto, A. C. Os Camisas Azuis: ideologia, elites e movimentos fascistas em Portugal, 1914-1945. Lisboa: Editorial Estampa, 1994.

. A queda da $1^{a}$ República Portuguesa: uma interpretação. In: BAIÔA, M. (dir.). Elites e poder: a crise do sistema liberal em Portugal e Espanha (1918-1931). Évora: Cidehus, 2004.

Pinto, A. C. (ed.). Corporatism and fascism: the corporatist wave in Europe. London: Routledge, 2017.

Pinto, A. C.; LARSEN, S. U. "Conclusion: fascism, dictators and charisma". Totalitarian Movements and Political Religions, vol. 7, no 2, p. 251-257, 2006.

Pinto, A. C.; MARtinho, F. P. (orgs.). O corporativismo em português: Estado, política e sociedade no salazarismo e no varguismo. Lisboa: Imprensa de Ciências Sociais, 2008.

A onda corporativa: corporativismo e ditaduras na Europa e na América Latina. Rio de Janeiro: FGV, p. 27-37, 2016.

PRIETO, M. H. A porta de marfim: evocação de Marcello Caetano. Lisboa: Verbo, 1992.

Putnam, R. D. "Bowling alone: America's declining social capital". Journal of Democracy, vol. 6, no 1, p. 65-78, 1995.

ROHDE, D. W. "Risk bearing and progressive ambition: the case of the United States House of Representatives". American Journal of Political Science, vol. 23, p. 1-26, 1979.

Rosas, F. Caetano, Marcelo José das Neves. In: Rosas, F.; BrITo, J. M. B. (coords.). Dicionário do Estado Novo, vol. I. Venda Nova: Bertrand, p. 110-113, 1996.

. História de Portugal. 70 vol. Lisboa: Edições Estampa, 1998.

. O marcelismo ou a falência da política de transição no Estado Novo. In: BRITo, J. M. B. (coord.). Do marcelismo ao fim do Império. Lisboa: Notícias, p. 15-59, 1999.

Salazar e o poder: a arte de saber durar. Lisboa: Tinta-da-China, 2012.

SCHLesinger, J. A. Ambition and politics: political careers in the United States. Chicago: Rand McNally, 1966.

Thomaz, A. Últimas décadas de Portugal. 4a vol. Lisboa: Fernando Pereira, 1983.

TORGAL, L. R. Estados novos, Estado Novo. Coimbra: Imprensa da Universidade de Coimbra, 2009. 
WeBer, M. Economia e sociedade: fundamentos da sociologia compreensiva. $2^{\circ}$ vol. São Paulo: Editora UnB; Imprensa Oficial, 2004.

\begin{abstract}
Marcelo Caetano and his circumstance towards leadership: symbolic power, ambition and adaptation

This article presents a model of symbolic power accumulation to explain Marcelo Caetano's political career and his progressive ambition towards the leadership of the Portuguese Estado Novo. This new model, with a reflexive and sociological basis, is applied to our case through an exercise of historical reconstruction of Marcelo's political path from his entrance in the corridors of power until his ascension to leadership in 1968. The article develops new theoretical arguments about the careers of political leaders and their objectives of obtaining political and social capital, especially the importance of accumulation of symbolic power in highly ideological and charismatic authoritarian regimes like the Estado Novo. Its main objective is to present a more sophisticated and relational vision of Marcelo Caetano's political path, namely by explaining the dilemma of charismatic succession with which he had to confront himself, and to contribute to the accumulation of theoretical and historical knowledge about the Portuguese authoritarian regime.
\end{abstract}

Keywords: Marcelo Caetano; political ambition; Estado Novo; symbolic power; political capital

\title{
Resumen
}

Marcelo Caetano y su circunstancia hacia el liderazgo: poder simbólico, ambición y adaptación

Este artículo presenta un modelo de acumulación de poder simbólico para explicar la carrera política de Marcelo Caetano y su ambición progresiva hacia el liderazgo del Estado Novo portugués. Este nuevo modelo, de base reflexiva y sociológica, se aplica a nuestro caso a través de un ejercicio de reconstrucción histórica del recorrido político de Marcelo desde su entrada en los pasillos del poder hasta su ascenso al liderazgo en 1968. El artículo desarrolla nuevos argumentos teóricos sobre las carreras de los líderes políticos y sus objetivos de obtener capital político y social, especialmente la importancia de la acumulación de poder simbólico en regímenes autoritarios altamente ideológicos y carismáticos como el Estado Novo. Su principal objetivo es presentar una visión más sofisticada y relacional de la trayectoria política de Marcelo Caetano, es decir, explicar el dilema de la sucesión carismática con el que tuvo que enfrentarse, y contribuir a la acumulación de conocimientos teóricos e históricos sobre el régimen autoritario portugués.

Palabras clave: Marcelo Caetano; ambición política; Estado Novo; poder simbólico; capital político

\section{Résumé}

Marcelo Caetano et son parcours vers le gouvernement: pouvoir symbolique, ambition et adaptation

Cet article présente un modèle d'accumulation de pouvoir symbolique pour expliquer la carrière politique de Marcelo Caetano et son ambition progressiste vers la direction de le Estado Novo portugais. Ce nouveau modèle, à base réflexive et sociologique, est appliqué à notre cas à travers un exercice de reconstruction historique du parcours politique de Marcelo depuis son entrée dans les couloirs du pouvoir jusqu'à son ascension au leadership en 1968. L'article développe de nouveaux arguments théoriques sur la carrière des dirigeants politiques et leurs objectifs d'obtention de capital politique et social, en particulier l'importance de l'accumulation du pouvoir symbolique dans les régimes autoritaires hautement idéologiques et charismatiques comme le Estado Novo. Son objectif principal est de présenter une vision plus sophistiquée et relationnelle du parcours politique de Marcelo Caetano, notamment en expliquant le dilemme de la succession charismatique auquel il a dû se confronter, et de contribuer à l'accumulation de connaissances théoriques et historiques sur le régime autoritaire portugais.

Mots-clés: Marcelo Caetano; ambition politique; Estado Novo; pouvoir symbolique; capital politique

Artigo submetido à publicação em 16 de junho de 2020. Versão final aprovada em 1 de julho de 2021.

Opinião Pública adota a licença Creative Commons CC-BY. 